\title{
Business ecosystems and new venture business models: an exploratory study of participation in the Lead To Win job-creation engine
}

\author{
Steven M. Muegge* and Mel Mezen \\ Technology Innovation Management, \\ Carleton University, \\ Ottawa, K1S 5B6, Canada \\ Email: steven.muegge@carleton.ca \\ Email: mel.mezen@gmail.com \\ *Corresponding author

\begin{abstract}
Technology entrepreneurs are launching and growing new businesses within business ecosystems, but little is known about how ecosystem participation impacts new venture business models. This research is an exploratory study of new venture business models within Lead To Win - a business ecosystem developed as a 'job-creation engine' for Canada's capital region. The three-phase research design is comprised of: 1) a field study of the Lead To Win field setting; 2) a multiple case-study of participating new ventures launched by six founders; 3) development of evidence-based propositions relating ecosystem participation and new venture business models. There are two key findings. First, more intense participation in the ecosystem is associated with higher business model differentiation, sophistication, and extent of change. Second, entrepreneurs participating more intensely in the ecosystem report a greater breadth of benefits.
\end{abstract}

Keywords: business ecosystem; business model; technology entrepreneurship; innovation; participation; new venture; job-creation engine; Ottawa; Canada; case study; entrepreneur.

Reference to this paper should be made as follows: Muegge, S.M. and Mezen, M. (2017) 'Business ecosystems and new venture business models: an exploratory study of participation in the Lead To Win job-creation engine', Int. J. Technology Management, Vol. 75, Nos. 1/2/3/4, pp.157-192.

Biographical notes: Steven Muegge is an Associate Professor at the Sprott School of Business at Carleton University in Ottawa, Canada, where he teaches and leads a research program within Carleton's Technology Innovation Management (TIM) program. His research, teaching, and community service interests include technology entrepreneurship, non-traditional settings for innovation and entrepreneurship (business ecosystems, communities, platforms, and interconnected systems that combine these elements) and business models of technology entrepreneurs (especially in non-traditional settings).

Mel Mezen received his MASc in Technology Innovation Management from Carleton University in Ottawa, Canada. He has more than 20 years of experience in telecommunications and engineering, primarily in the business of software product development and technologies. 


\section{Introduction}

Technology entrepreneurs are increasingly launching and growing their new business ventures within business ecosystems (Bailetti and Hurley, 2013; Muegge, 2013) interconnected systems of innovation and production that differ in important ways from traditional structures such as markets, corporate hierarchies, strategic alliances, and supply chains (Moore, 1993, 2006; Iansiti and Levien, 2004; Adner, 2012). Concurrently, management scholars and practitioners are increasingly concerned with business models - explanations of how a business delivers value to a set of stakeholders at a profit (Chesbrough and Rosenbloom, 2002; Chesbrough, 2006; Johnson et al., 2008; Johnson, 2010; Osterwalder and Pigneur, 2010; George and Bock, 2011; Muegge, 2012; Muegge and Haw, 2013). Some scholars have previously proposed a connection between business ecosystems and business models. For example, Teece (2009) argues that business ecosystems are the new context for opportunity discovery, business model shaping, and competition. The role of context in shaping managerial outcomes is previously well-established in various domains of management inquiry including organisation theory (Scott and Davis, 2007), strategy (Mintzberg et al., 1998), entrepreneurship (Aldrich, 2011), and marketing (Simmons et al., 2013), thus context may be similarly important for shaping new venture business models. Currently, however, there is a paucity of technology entrepreneurship research at the intersection of business ecosystems and business models. That gap in the literature is the motivation for our research question: how does new venture participation in a business ecosystem impact new venture business models?

This article presents the findings from an exploratory study of new venture business models within Lead To Win - "an ecosystem-based job-creation engine fueled by technology entrepreneurs" in Canada's Capital Region [Bailetti and Bot, (2013), p.31]. It reports on the Lead To Win field setting, the ecosystem participation and business models of six case companies, and the relationships between the field setting properties, company participation, company business models, and the benefits reported by founders. This work differs from prior research in at least three salient ways. First, with few exceptions, including Muegge (2011b) and Kapoor (2013), scholarly research on business ecosystems has emphasised the benefits and strategies of the organisations that play a central role in the ecosystem - as platform leaders (Gawer and Cusumano, 2002; Gawer, 2009), keystone organisations (Iansiti and Levien, 2004), orchestrators (Adner, 2012), and other related and overlapping central constructs; this research contributes to the nascent and under-developed literature on smaller and non-central 'niche players' (Iansiti and Levien, 2004) that collectively comprise the ecosystem periphery. Second, extant research has emphasised business ecosystems anchored around product platforms implemented using information technology (IT) hardware and software, and orchestrated by profit-motivated keystone organisations; this study examines a venture-creation ecosystem anchored around a process platform and a non-traditional keystone organisation. Process here refers not to an algorithm in an IT system, but rather a venture creation process (Bailetti and Bot, 2013) comprised of a venture lifecycle with engagement points where ecosystem participants - including investors, early users and buyers, economic development organisations, service providers, and other entrepreneurs pursuing complementary opportunities - get involved in particular ways. Third, consistent with the theme of this special issue of the International Journal of Technology 
Management, this research brings together the notions of business models and business ecosystems, which have typically been examined separately in prior work.

The article is organised as follows. In the next two sections, we review the salient scholarly and practitioner literature on business ecosystems and on business models and explore possible connections. Next, we specify the research design and the method for each of the three phases of the design. In the next three sections, we present the results of each phase. The final two sections are discussion and conclusions.

\section{Business ecosystems}

The business ecosystem concept entered management discourse with James Moore's 1993 McKinsey Award-winning Harvard Business Review article, 'Predators and prey: a new ecology of competition'. Moore (1993) argued that modern businesses reside not within a single industry sector but rather within a business ecosystem that crosses multiple industries. A follow-up book [Moore, (1996), p.26] described the business ecosystem as "an economic community supported by a foundation of interacting organizations and individuals - the organisms of the business world", and later writing (Moore, 2006) described the business ecosystem in two ways: a network of specialised and complementary opportunity niches, some known and some not yet discovered, and a mode of organising economic production that differs from markets and the organisational hierarchies of firms. Iansiti and Levien (2004) introduced the notion of a keystone organisation - a firm occupying an influential hub position that exercises leadership for their own benefit and also to the benefit of other members.

Examples of business ecosystems examined by management researchers include the 'Wintel' personal computer ecosystem of independent software vendors anchored around Microsoft software and Intel hardware [Moore, (2006), pp.48-58], the network of companies and individuals utilising Google's search and advertising platform (Iyer and Davenport, 2008), the Amazon ecosystem of e-commerce and cloud computing (Isckia, 2009), the Eclipse ecosystem of companies that use, consume, extend and develop complements to Eclipse open source software frameworks and tools (Muegge, 2011b; Muegge and Grant, 2013), and the failed Symbian ecosystem of system integrators, component vendors, mobile service providers and others whose business depended on the Symbian mobile operating system (West and Wood, 2013). Within each of these systems, companies compete and collaborate with others (Brandenburger and Nalebuff, 1996; Adner, 2006, 2012; Adner and Kapoor, 2010) while co-evolving capabilities around a platform of shared assets (Gawer, 2009; Baldwin and Woodard, 2009; Cusumano, 2010). Ecosystem discourse is particularly evident around information and communication technology platforms, but is also observed in sectors as diverse as health care, transportation subsystems, and semiconductor lithography equipment (e.g., Kapoor and Adner, 2007; Gawer, 2009; Adner, 2012). Business ecosystems often coexist with communities, platforms, and other non-traditional settings for innovation (Muegge, 2013), all bound together by what Moore (2006) calls the 'shared fate' of interconnected actions and outcomes.

There is, as yet, no consensus among researchers about how to describe and characterise a business ecosystem (Baldwin and Woodard, 2009; Muegge, 2013; Gawer and Cusumano, 2014). Prior research has proposed at least five frameworks: 
1 a semantic framework (Muegge, 2011a) to make explicit the different meanings that attach to the words 'business ecosystem' and the often unacknowledged similarities and differences between various ecosystem constructs proposed in the literature

2 an architectural perspective of platform modularity and option value (Baldwin and Clark, 2000, 2006)

3 an economic perspective of multisided platforms (MSPs) (Iyer and Davenport, 2008; Bailetti, 2010b) emphasising stakeholder groups and value propositions for each group to participate

4 community design dimensions that describe the community architecture for individual participation (West and O'Mahony, 2008)

5 a systems perspective of codependent subsystems (Muegge, 2011b) linked by an architecture of institutional arrangements, resource flows, and governance structures

Table 1 describes the five frameworks.

Table 1 Five frameworks to describe and explain business ecosystems

\begin{tabular}{ll}
\hline Framework & \multicolumn{1}{c}{ Description and central constructs } \\
\hline $\begin{array}{l}\text { Semantic } \\
\text { framework } \\
\text { (Muegge, 2011a) }\end{array}$ & $\begin{array}{l}\text { Business ecosystem constructs can differ in at least four dimensions: } \\
\text { conceptual location of the ecosystem construct: whether the business } \\
\text { ecosystem is a level of analysis above the firm (Iansiti and Levien, } \\
\text { 2004), or an economic mode of production that is an alternative to the } \\
\text { firm (Moore, 2006), or something else } \\
\text { anchor point: whether the business ecosystem is anchored around a } \\
\text { shared platform, a focal firm, something else, or has no identifiable } \\
\text { anchor }\end{array}$ \\
& $\begin{array}{l}\text { ecosystem boundaries: whether the ecosystem is bounded by proximity } \\
\text { of members to the ecosystem anchor, a firm-level property such as } \\
\text { membership or industry sector code (Iansiti and Richards, 2006), or } \\
\text { something else }\end{array}$ \\
& $\begin{array}{l}\text { nature of the elements that comprise the ecosystem: elements could be } \\
\text { organisations, individuals, technologies, or something else entirely, or } \\
\text { multiple types of entities at different levels of analysis. }\end{array}$ \\
& $\begin{array}{l}\text { Researchers could improve the clarity of their arguments by explicitly } \\
\text { situating their own ecosystem construct within the conceptual space } \\
\text { spanned by these four dimensions. }\end{array}$ \\
Platform architectures vary in modularity and option value. \\
$\begin{array}{l}\text { Platform } \\
\text { modularity and } \\
\text { option value } \\
\text { (Baldwin and } \\
\text { Clark, 2000, 2006) }\end{array}$ \\
$\begin{array}{l}\text { A more modular platform enables experimentation and changes within } \\
\text { modules with less disturbance to the whole system (Parnas, 1972; Simon, } \\
\text { 1996; Baldwin and Woodard, 2009). } \\
\text { A platform design and its modules have option-value (Merton, 1973) } \\
\text { because a new design creates the opportunity but not the obligation to adopt } \\
\text { it. } \\
\text { Platforms with greater modularity and option value are more likely to } \\
\text { attract voluntary participation (Baldwin and Clark, 2006), are more flexible } \\
\text { to use and repurpose (MacCormack et al., 2001, 2006), and may improve } \\
\text { more rapidly through the selection forces of design evolution (Baldwin and } \\
\text { Clark, 2000). }\end{array}$ \\
\hline
\end{tabular}


Table 1 Five frameworks to describe and explain business ecosystems (continued)

\begin{tabular}{|c|c|}
\hline Framework & Description and central constructs \\
\hline \multirow[t]{3}{*}{$\begin{array}{l}\text { MSP } \\
\text { (Iyer and } \\
\text { Davenport, 2008; } \\
\text { Bailetti, 2009b) }\end{array}$} & $\begin{array}{l}\text { An MSP is an economic intermediary that enables interaction between two } \\
\text { or more groups of stakeholders. Each stakeholder group benefits from these } \\
\text { interactions in ways that are often different from the traditional } \\
\text { supply-chain roles of supplier and customer. }\end{array}$ \\
\hline & $\begin{array}{l}\text { Some MSPs are implemented as information systems, constructed with } \\
\text { 'digital technologies connected to the internet' (e.g., Yoo, 2013), but the } \\
\text { MSP is fundamentally an economic construct (Rochet and Tirole, 2003, } \\
\text { 2006) anchored in the economics of network externalities and multi-product } \\
\text { pricing (Katz and Shapiro, 1985), and not necessarily an IT artefact per se } \\
\text { (q.v., Gawer, 2009; Baldwin and Woodard, 2009; Gawer, 2014). }\end{array}$ \\
\hline & $\begin{array}{l}\text { Recent research has examined tactics for developing and growing MSPs } \\
\text { (e.g., Evans, 2009; Edelman, 2015; Parker et al., 2016; Evans and } \\
\text { Schmalensee, 2016) and conceptual developments required to better } \\
\text { connect the economics and architectural platform perspectives at a } \\
\text { theoretical level (e.g., Boudreau and Hagiu, 2009; Gawer, 2014). }\end{array}$ \\
\hline \multirow{5}{*}{$\begin{array}{l}\text { Community design } \\
\text { dimensions (West } \\
\text { and O'Mahony, } \\
\text { 2008) }\end{array}$} & $\begin{array}{l}\text { Three community design dimensions together create a community } \\
\text { participation architecture: }\end{array}$ \\
\hline & $\begin{array}{l}1 \text { production is the way that the community conducts production } \\
\text { processes }\end{array}$ \\
\hline & 2 governance is the set of processes by which decisions are made \\
\hline & $\begin{array}{l}3 \text { intellectual property (IP) rights are the allocation of rights to use } \\
\text { community outputs. }\end{array}$ \\
\hline & $\begin{array}{l}\text { Community-developed platforms with more transparent and accessible } \\
\text { production, governance and IP rights attract more voluntary participation } \\
\text { (West and O'Mahony (2008). }\end{array}$ \\
\hline \multirow[t]{2}{*}{$\begin{array}{l}\text { Codependent } \\
\text { subsystems } \\
\text { (Muegge, 2011b) }\end{array}$} & $\begin{array}{l}\text { An ecosystem field setting is a system comprised of codependent } \\
\text { subsystems linked by an architecture of interconnected institutional } \\
\text { arrangements (North, 1990; Ostrom, 2005), resource flows (Pfeffer and } \\
\text { Salancik, 1978), and governance structures (Ostrom, 1990; Hess and } \\
\text { Ostrom, 2007). Subsystems may include technical platforms, organisations } \\
\text { of people, and networks of economic actors joined in a complex multilevel } \\
\text { hierarchical system. }\end{array}$ \\
\hline & $\begin{array}{l}\text { Positive feedback loops drive growth; negative feedback loops accelerate } \\
\text { decline. }\end{array}$ \\
\hline
\end{tabular}

Each framework brings into sharp focus aspects of the phenomenon that are unaddressed or under-addressed by other frameworks (Muegge, 2013). None is a substitute for any other. The semantic framework excels at sharply defining the ecosystem construct, boundary conditions, and criteria of which phenomena are internal and which are external, but is silent about interactions and activities within and across the boundary. The platform modularity and MSP perspectives represent the ecosystem platform in different ways; the former is an engineering perspective emphasising components, interfaces, and interconnections, and the latter is an economics perspective about transactions, and neither attends to the main concerns of the other (Gawer, 2014). The community design dimensions represent the community component present in some ecosystems, explicitly operationalising platform production, governance, and property rights - aspects of the ecosystem about which other perspectives are silent. Finally, the 
codependent subsystems perspective uniquely attends to activity systems and resource flows within the ecosystem and across its boundaries but is the least mature framework and the most demanding of field data, and requires other constructs to specify subsystems. The conceptual and theoretical work to unify these perspectives is underway but thus far incomplete (Muegge, 2011b, 2013; Gawer, 2014). We treat these frameworks as partly complementary and partly overlapping, each providing partial yet incomplete representations of the business ecosystem phenomena, subsystems, and boundaries. Muegge (2011a) previously demonstrated the effectiveness of employing multiple conceptual perspectives to more fully describe a business ecosystem field setting. We adopt that approach here to employ all five frameworks to guide data collection and analysis.

\section{Business models}

The business model concept entered management discourse with the emergence of e-businesses utilising the internet to conduct business in new ways (Amit and Zott, 2001). The explanation for recent attention seems to be proliferation of alternatives that were previously unavailable (Teece, 2010; George and Bock, 2012; Zott and Amit, 2013) - enabled by abundant information (Shapiro and Varian, 1999; Friedman, 2005), networked computing (Yoo, 2013), digital distribution channels (Timmers, 1998), new ways of conducting transactions (Amit and Zott, 2001; Shin and Park, 2009), the increasing role of software (Messerschmitt and Szyperski, 2003; Cusumano, 2004), expectations that information services have zero cost (Anderson, 2010), viability of new forms and loci of innovation (Chesbrough, 2006; Shirky, 2008; Baldwin and von Hippel, 2011; Chanal and Caron-Fason, 2010), and the increasing ease and fast pace of entrepreneurial activity (George and Bock, 2012; Blank, 2013). Businesses in the past were more alike than businesses today (Teece, 2010), requiring now a greater focus on design.

A business model explains how a firm delivers value to customers at attractive profits (Magretta, 2002; Johnson, 2010). "It must create value within the value chain; and it must capture a piece of value for the focal firm in that chain" [Chesbrough et al., (2006), p.31]. "It thus reflects management's hypothesis about what customers want, how they want it, and how the enterprise can organize to best meet those needs, get paid for doing so, and make a profit" [Teece, (2010), p.173]. It simultaneously embodies multiple forms of 'model' - as a means to describe and classify businesses, as sites for scientific investigation, and as recipes for managers (Baden-Fuller and Morgan, 2010).

According to Amit and Zott (2001), business models can create value for a focal firm in four ways: efficiency (anchored in actions to reduce transaction costs), novelty (new ways of conducting economic exchanges among participants), complementarities (anchored in resource-based theory) and lock-in (inherent in strategic networks). Empirical research reports improved performance from novelty-centred business models (Zott and Amit, 2007), novelty-centred business models combined with product differentiation, cost leadership, and early market entry (Zott and Amit, 2008), differentiated business models unlike those of competitors (Shin and Park, 2009; 
Cennamo and Santalo, 2013), and business model innovation - sometimes without changing products (Simmons et al., 2013).

Zott et al. (2011) organise the business model literature into three streams: e-commerce explores ways to classify business models, strategy explores value creation mechanisms and competitive advantage, and technology and innovation management explores technology conversion into market outcomes. Common themes include business models as a useful unit of analysis, practical value of system-level explanations of businesses, simultaneous focus on value creation for stakeholders and value capture by focal firms, and stakeholder activities. Research has examined connections with industrial marketing (Coombes and Nicholson, 2013) and platform strategy (Cennamo and Santalo, 2013), business models to commercialise disruptive innovations (Johnson et al., 2008; Christensen et al., 2008; Johnson, 2010; Simmons et al., 2013), business models as cognitive configurations manipulable in the minds of managers (Baden-Fuller and Mangematin, 2013), treating customers as resources (Plé et al., 2010), and business models featuring networks (Palo and Tähtinen, 2013) and collaboration with competitors (Ritala et al., 2014). The viability of different innovation modes may be a function of time and technology (Baldwin and von Hippel, 2011); as design and communications costs decrease, business models utilising open collaborative innovation becomes feasible.

There is no general agreement about how to specify a business model (Al-Debei and Avison, 2010; George and Bock, 2011; Zott et al., 2011). Numerous operational representations have been proposed, including the open innovation framework of Chesbrough (2003, 2006), the six-component framework of Morris et al. (2005), the seizing the whitespace framework of Johnson et al. (2008), the business model canvas of Osterwalder and Pigneur (2010), and the technology entrepreneurship framework of Muegge (2012; q.v., Muegge and Haw, 2013).

We selected the technology entrepreneurship framework (Muegge, 2012) comprised of four components (described in Table 2): a problem space, a set of stakeholder value propositions (SVPs), a profit formula explaining revenues, costs, and profits (Johnson, 2010), and critical-to-success capabilities. Muegge (2012) adapted this framework from multiple sources including the frameworks of Johnson, Chesbrough and Osterwalder, the nascent research literature on technology entrepreneurship (Bailetti, 2012; Bailetti et al., 2012), and the experience of Lead To Win organisers (Muegge and Haw, 2013). Standardising on this framework offered several benefits. First, it was familiar to some respondents from training material and advisory services, thus simplifying data acquisition. Second, the components are tuned specifically to the realities of technology entrepreneurs and technology-intensive ventures - especially dependence on multiple stakeholders that are neither customers nor suppliers, and needs for capabilities that are neither owned nor controlled. Lead To Win ventures are known to utilise MSPs, open source software, novel systems of innovation, and ecosystem growth strategies (Bailetti, 2009a, 2010a, 2010c), thus we need a framework capable of describing business models with these features. Third, the framework's parsimony and simplicity required a relatively small number of non-technical, plain-language interview questions to complete. Fourth, business models expressed in this framework can be mapped to the frameworks of Johnson, Chesbrough, and Osterwalder using the approach described by Muegge (2012, p.10, Table 2). 
Table 2 Technology entrepreneurship business model framework

\begin{tabular}{|c|c|}
\hline Component & Description of component \\
\hline Problem space & $\begin{array}{l}\text { The problem space or pain point can be expressed as an underlying } \\
\text { job-to-be-done (Christensen et al., 2007), a problem-to-be-solved, or a set of } \\
\text { unmet needs. }\end{array}$ \\
\hline \multirow{2}{*}{$\begin{array}{l}\text { Stakeholder } \\
\text { value } \\
\text { propositions } \\
\text { (SVPs) }\end{array}$} & $\begin{array}{l}\text { The set of SVPs is expressed as points of difference and points of parity with } \\
\text { respect to alternatives (Anderson et al., 2006) for each stakeholder group. }\end{array}$ \\
\hline & $\begin{array}{l}\text { Customer value propositions are necessary but often not sufficient to } \\
\text { adequately describe the value to stakeholders. Businesses that depend on } \\
\text { multiple stakeholders with differing motivations - for example, the groups } \\
\text { brought together by a digital platform (Cennamo and Santalo, 2013; } \\
\text { Edelman, 2015), the participants of an innovation community (Chanal and } \\
\text { Caron-Fason, 2010), or the firms operating within a partner network (Palo } \\
\text { and Tähtinen, 2013) with critical suppliers or complementors (Brandenburger } \\
\text { and Nalebuff, 1996; Yoffie and Kwak, 2006) - have multiple value } \\
\text { propositions that express how each stakeholder group experiences value } \\
\text { differently. }\end{array}$ \\
\hline \multirow[t]{2}{*}{ Profit formula } & $\begin{array}{l}\text { The profit formula is expressed as an explanation of revenues and costs, and } \\
\text { why revenues exceed costs to produce attractive profits (Johnson, 2010). }\end{array}$ \\
\hline & $\begin{array}{l}\text { For businesses with multiple stakeholder groups, the explanation of revenues } \\
\text { includes who pays (one group or multiple groups) and the revenue trigger for } \\
\text { the transaction (how each group pays and what specifically they pay for, e.g., } \\
\text { a product, a subscription, or something else). }\end{array}$ \\
\hline Capabilities & $\begin{array}{l}\text { Capabilities are expressed as an explanation of the critical-to-success } \\
\text { resources, processes, and other complementary assets needed to deliver on } \\
\text { the SVPs while earning attractive profits, and an explanation of how the firm } \\
\text { will obtain access to those capabilities. }\end{array}$ \\
\hline
\end{tabular}

\section{Source: Adapted from Muegge (2012)}

New venture business models are discovered through search and heuristic logic (Chesbrough and Rosenbloom, 2002). According to Teece (2010, p.187), "the right business model may not be apparent up front ... Experimentation and learning is likely to be required". Our research question thus requires us to examine the larger history of a venture over time.

Prior scholars have speculated about connections between business models and business ecosystems. Teece (2010, p.189) writes: "a provisional business model must be evaluated against the current state of the business ecosystem, and against how it might evolve" - thus in this view, the business ecosystem is the context for business model discovery and shaping (Teece, 2009). Zott and Amit (2013) describe ecosystems and business models as 'adjacent bodies of literature' (p.403) examining value creation systems with different boundaries and anchors. Muegge (2013, pp.5-6) argues that participation in business ecosystems may be a partial remedy to the problems faced today by technology entrepreneurs:

"By building products and services on platform assets developed by others, a technology entrepreneur can focus R\&D effort on building differentiating capability. By engaging communities of passionate people, a technology entrepreneur can learn more effectively about individual wants and needs, benefit from user innovations, and channel the creative energy of the community towards useful endeavours. By operating a business within a networked ecosystem of interdependent and codependent businesses with 
partially aligned incentives, a technology entrepreneur can achieve more, learn faster, and reach farther than otherwise possible, while sharing some of the risks and costs with others."

Ideas shared by both literatures include innovation, value creation and capture, interactions between stakeholder groups, activity systems, and access to resources, processes, and complementary assets. Business ecosystems thus touch all four components of a new venture's business model: the context in which opportunities are discovered and shaped, access to complementors and collaborators that can strengthen SVPs, reducing cost structures, increasing operational efficiencies, and improving access to sources of revenue, and access to capabilities. Business ecosystems may also accelerate learning by increasing frequency and diversity of interactions with others. However, the precise nature of these relationships is not developed in either literature, nor have these relationships been examined empirically.

\section{Research design and method}

We employ a nested exploratory multiple case study research design (Yin, 2003). Our nested design examines the 'phenomena within the phenomena' (Christensen, 2006) of business models within a business ecosystem field setting to reveal insights that would be unnoticed at either level without the other. An exploratory design investigates phenomena about which little is known (Yin, 2003); despite much research about business ecosystems and about business models, little is known about their intersection. Multiple cases enable cross-case comparison (Eisenhardt, 1989; Miles and Huberman, 1994) - an effective research design for building theory from case data (Eisenhardt and Graebner, 2007; Eisenhardt et al., 2016).

We selected the Lead To Win 'job-creation engine' as our business ecosystem field setting. Selecting one business ecosystem rather than multiple ecosystems controls for contextual and environmental variables across all nested cases. Selecting Lead To Win rather than a different field setting was motivated by five factors. First, Lead To Win was deliberately structured as a business ecosystem by its founders (Bailetti and Hudson, 2009) and participants self-identify as belonging to a business ecosystem. Second, as a business ecosystem "fueled by technology entrepreneurs" [Bailetti and Bot, (2013), p.31], we expected an abundance potential case studies. Third, it is accessible; we expected participants would share their stories with us. Fourth, business ecosystems are prominent in training material thus we expected that effects of ecosystem participation may be more pronounced and easier to detect than in other field settings. Fifth, Lead To Win differs in important ways from ecosystems more typically studied by prior researchers thus we expected to discover novel insights not previously reported.

We employed a three-phase research design, described in Table 3, comprised of a field study of the ecosystem (phase 1), a multiple case-study of new ventures (phase 2), and theory-building (phase 3) to develop explanations and propositions connecting the results of phases 1 and 2 . Our research question required contextualised data and theorising at multiple levels of analysis, motivating our choice of a phased design. 
Table 3 Research method (steps of the three-phase research design)

\begin{tabular}{|c|c|}
\hline Phase & Steps of each phase \\
\hline $\begin{array}{l}\text { Phase 1: } \\
\text { Field study of } \\
\text { the Lead To } \\
\text { Win field } \\
\text { setting } \\
\text { (four steps) }\end{array}$ & $\begin{array}{l}\text { Review of archival sources: we began with keyword search of databases, } \\
\text { search engines, and specific publications, including EBSCO Business Source } \\
\text { Complete (BSC), Google Scholar, the Technology Innovation Management } \\
\text { Review (an open access journal known to publish articles about Lead To } \\
\text { Win), Carleton University Magazine (known to publish articles about Lead } \\
\text { To Win), and three newspapers - a national daily (The Globe and Mail), a } \\
\text { local daily (the Ottawa Citizen), and a local weekly business journal (the } \\
\text { Ottawa Business Journal). We searched on keywords 'Lead To Win' (with } \\
\text { the 'case sensitive' delimiter unchecked), and categorised a keyword hit as } \\
\text { 'relevant' if the corresponding source included information about the field } \\
\text { setting or participants, and as 'not relevant' otherwise. }\end{array}$ \\
\hline
\end{tabular}

Field setting interviews: we selected four respondents familiar with different aspects of Lead To Win; all agreed to participate. We developed an interview guide for each respondent then conducted semistructured interviews following the best practices recommended by Foddy (1993). Phase 1 interviews varied in duration from ninety minutes to two hours and fifteen minutes. Some respondents provided documents that were not publicly available. Our mix of interview and archival data permitted triangulation from multiple sources (Jick, 1979).

3 Field setting case report: we developed a field setting case report that described the setting using the five frameworks from the management literature.

4 Follow-ups with respondents: We solicited feedback on preliminary findings, then produced an updated version of the field setting case report.

Phase 2:

Multiple case

study of participating new ventures (four steps)
1 List of candidates: we compiled a list of candidate ventures and founders using publicly-available sources and information from phase 1 .

2 Case reports: we began by selecting our first two cases from the list of candidates, then contacted the founding entrepreneurs; both agreed to participate. We collected archival sources, developed interview guides, and conducted semistructured interviews. The phase 2 interviews ranged in duration from sixty minutes to ninety minutes. We developed a case report for each case. Each case report followed the same template so that information was presented in a consistent way. This template was updated while the research was underway; at each revision, we also revised previously completed cases. After completion of the first two case reports, we selected two more cases from the list of candidates and repeated the process to produce the third and fourth case reports. Finally, we repeated the process again to produce the fifth and sixth case reports. We chose purposive sampling [Yin, (2011), p.88] to select a set of cases with high variation regarding founding circumstances, participation in the ecosystem, and outcomes. We stopped at six cases - within the range of four to ten cases recommended by Eisenhardt (1989, p.545) for building theory from case data.

3 Follow-ups with respondents: we invited founders to review portions of the case reports, correct any factual errors, and provide feedback on our draft results, then we produced updated versions of each case report. The completed reports ranged in length from 20 to 25 pages of text, tables and figures.

4 Cross-case analysis: we conducted cross-case analysis of the six cases and produced a cross-case report with timelines and tabular displays comparing cases. 
Table 3 Research method (steps of the three-phase research design) (continued)

\begin{tabular}{lrl}
\hline Phase & \multicolumn{1}{c}{ Steps of each phase } \\
\hline $\begin{array}{l}\text { Phase 3: } \\
\begin{array}{l}\text { Theory } \\
\text { building } \\
\text { (three steps) }\end{array}\end{array}$ & $\begin{array}{l}\text { Variables and measures: we developed a set of case-level variables for } \\
\text { ecosystem participation, business models, and benefits of participation, and } \\
\text { assigned values to the variables for each case. }\end{array}$ \\
& $2 \begin{array}{l}\text { Tabular comparisons: we constructed tables of possible dependent variables } \\
\text { sequenced by possible independent variables and looked for patterns. }\end{array}$ \\
3 & $\begin{array}{l}\text { Propositions: we developed propositions to account for patterns observed in } \\
\text { the case data. Inducing propositions using replication logic is a } \\
\text { well-established approach to building theory from case data (Eisenhardt, } \\
\text { 1989; Yin, 2003, 2011). }\end{array}$ \\
\hline
\end{tabular}

Following the best practices of Yin $(2003,2011)$, the interview guides and case report for phase 1 distinguished between three levels of phase 1 questions. Our first and highest level was a guiding question about the field setting: to what extent can we describe and explain Lead To Win using the business ecosystem frameworks from the management literature? Our second level was a list of researcher questions implied by the various frameworks in the technical language of the literature. For example: what are the SVPS for each group of stakeholders? Our third level was interview questions posed in plain managerial language with no technical jargon, including some open-ended questions and some narrow and specific questions referring directly to features of Lead To Win. For example: why do economic development organisations participate in Lead To Win? We deliberately posed different sets of questions to each respondent to incorporate learning from previous interviews and to query aspects of Lead To Win about which each respondent was most knowledgeable.

Phase 2 began with three initial phase 2 questions:

1 What are the new venture business models?

2 What participation occurred in the business ecosystem?

3 What were the benefits of participation?

The initial unit of analysis was the business venture. While the research was underway, we expanded the unit of analysis to also include multiple ventures from the same founder if we observed strong connections between venture business models. Flexibility to revise the research while underway (Yin, 2003) was a valued feature of our exploratory design.

Table 4 summaries keyword search results about the field setting and seventeen relevant articles. Table 5 summarises primary and secondary data sources for the six company cases. 
Table 4 Results of keyword search on 'Lead To Win' (conducted 1 September 2013)

\begin{tabular}{|c|c|c|c|c|}
\hline Database or publication & Type & $\begin{array}{l}\text { Count of } \\
\text { keyword } \\
\text { hits }\end{array}$ & $\begin{array}{l}\text { Count of } \\
\text { relevant } \\
\text { articles }\end{array}$ & Citations to relevant articles \\
\hline $\begin{array}{l}\text { Technology Innovation } \\
\text { Management Review } \\
\text { (http://timreview.ca) }\end{array}$ & $\begin{array}{l}\text { Peer-reviewed } \\
\text { journal }\end{array}$ & 45 & 8 & $\begin{array}{l}\text { Bailetti and Hudson (2009), } \\
\text { Bailetti and Prattico (2011), } \\
\text { Bailetti (2010a), Wacheski } \\
\text { (2011), Makienko and Misaka } \\
\text { (2011), Singer and Dexter } \\
\text { (2011), Muegge (2012) and } \\
\text { Bailetti and Bot (2013) }\end{array}$ \\
\hline $\begin{array}{l}\text { Ottawa Business } \\
\text { Journal }\end{array}$ & $\begin{array}{l}\text { Newspaper: } \\
\text { local business } \\
\text { journal }\end{array}$ & 24 & 7 & $\begin{array}{c}\text { Bailetti (2009a, 2009b, 2010c), } \\
\text { Ottawa Business Journal } \\
(2009 \mathrm{a} ; 2009 \mathrm{~b}, 2009 \mathrm{c}) \text { and } \\
\text { Symons }(2012)\end{array}$ \\
\hline $\begin{array}{l}\text { Carleton University } \\
\text { Magazine }\end{array}$ & Magazine & 2 & 2 & $\begin{array}{l}\text { Couch (2012) and Hickman } \\
\text { (2013) }\end{array}$ \\
\hline Google Scholar & Search engine & $\sim 1,100$ & 0 & \\
\hline $\begin{array}{l}\text { Business Source } \\
\text { Complete }\end{array}$ & Database & 17 & 0 & \\
\hline Ottawa Citizen & $\begin{array}{l}\text { Newspaper: } \\
\text { local daily }\end{array}$ & 0 & 0 & \\
\hline The Globe and Mail & $\begin{array}{l}\text { Newspaper: } \\
\text { national daily }\end{array}$ & 0 & 0 & \\
\hline
\end{tabular}

Table 5 Primary and secondary sources for phase 2

\begin{tabular}{|c|c|c|c|c|c|c|c|c|}
\hline \multirow[b]{2}{*}{ Case } & \multicolumn{2}{|c|}{ Primary sources } & \multicolumn{6}{|c|}{ Archival sources } \\
\hline & $\begin{array}{l}\text { Founder } \\
\text { interviews }\end{array}$ & $\begin{array}{l}\text { Other primary } \\
\text { sources }\end{array}$ & Total & $\begin{array}{l}\text { Articles in } \\
\text { scholarly } \\
\quad \text { and } \\
\text { practitioner } \\
\text { journals }\end{array}$ & $\begin{array}{l}\text { Articles } \\
\text { in the } \\
\text { business } 1 \\
\text { press }\end{array}$ & $\begin{array}{l}\text { Press } \\
\text { releases }\end{array}$ & $\begin{array}{l}\text { Books } \\
\text { and } \\
\text { book } \\
\text { chapters }\end{array}$ & $\begin{array}{l}\text { Other } \\
\text { archival } \\
\text { sources }\end{array}$ \\
\hline A & 1 & & 21 & 2 & 12 & 2 & 2 & 3 \\
\hline B & 1 & $\begin{array}{l}\text { Respondent } \\
\text { corrections to case } \\
\text { report. More timeline } \\
\text { details. }\end{array}$ & 12 & 3 & - & 6 & - & 3 \\
\hline $\mathrm{C}$ & 1 & $\begin{array}{l}\text { Respondent } \\
\text { corrections to case } \\
\text { report. More financing } \\
\text { information. }\end{array}$ & 10 & 1 & 5 & - & - & 4 \\
\hline D & 1 & & 6 & - & 3 & - & - & 3 \\
\hline E & 1 & $\begin{array}{l}\text { Interview with } \\
\text { business analyst }\end{array}$ & 7 & - & 4 & - & - & 3 \\
\hline $\mathrm{F}$ & 1 & $\begin{array}{l}\text { Respondent } \\
\text { corrections to case } \\
\text { report. New } \\
\text { information about } \\
\text { recent developments. }\end{array}$ & 8 & 3 & - & 1 & - & 4 \\
\hline
\end{tabular}




\title{
5 Results of phase 1: The Lead To Win field setting
}

Lead To Win launched in 2002 with a single cohort then re-launched in 2009. A case study published in the University Industry Innovation Network (UIIN) Good Practice Series (Bailetti et al., 2014) describes Lead To Win as follows:

\begin{abstract}
Carleton University's Lead To Win ecosystem delivers services to technology entrepreneurs for the purpose of creating knowledge jobs in Canada's Capital Region. It brings together assets, partnerships, and programs at the university and community level. As the keystone, Carleton University, located in Ottawa, Canada, establishes and operates lead projects around challenging problems, supports entrepreneurs to launch and grow their ventures, provides them with access to global partnerships and to a shared infrastructure, and helps them monitor their progress.
\end{abstract}

As of February 2014, the Lead To Win ecosystem has raised $\$ 7.75 \mathrm{M}$, reviewed 339 opportunities, graduated 91 ventures that will create a minimum of six jobs in three years, published $400+$ articles in our online journal, and received numerous awards.

The Lead To Win ecosystem was [re-]launched in 2009 in response to the recent and dramatic economic downturn in the Ottawa region. The downturn's effects included loss of technology jobs, withdrawal of venture capital, the break-up of the largest local private sector technology company (Nortel), and the need to adjust to the realities of the new economy.

Lead To Win was identified as a 'North American Top 10 University Business Incubator' in the UBI Global 2015 benchmark of more than 330 incubators in 64 countries and six geographical regions, ranked seventh in its category (Rubinstein, 2015; UBI Global, 2015).

Table 6 compiles excerpts of archival sources describing Lead To Win.

Table 6 How sources explain Lead To Win

\begin{tabular}{|c|c|}
\hline Source & Explanation of Lead To Win \\
\hline $\begin{array}{l}\text { Bailetti } \\
\text { (2009a) }\end{array}$ & $\begin{array}{l}\text { "Lead To Win [is] an ecosystem designed to launch and grow creative companies } \\
\text { in Canada's Capital Region" }\end{array}$ \\
\hline $\begin{array}{l}\text { Bailetti and } \\
\text { Hudson } \\
(2009)\end{array}$ & $\begin{array}{l}\text { "Lead To Win is a business ecosystem designed to create technology jobs and } \\
\text { attract investment into technology companies that operate in Canada's Capital } \\
\text { Region" (p.11) }\end{array}$ \\
\hline \multirow{2}{*}{$\begin{array}{l}\text { Ottawa } \\
\text { Business } \\
\text { Journal } \\
(2009 a)\end{array}$} & $\begin{array}{l}\text { "The program will combine classroom training and mentorship, along with the } \\
\text { added use of facilities from business incubators such as TheCodeFactory and } \\
\text { Vitesse Re-Skilling." }\end{array}$ \\
\hline & $\begin{array}{l}\text { "[The Lead To Win] ecosystem includes support from high-powered partners such } \\
\text { as the Chamber of Commerce. In a recent report presented to the Corporate } \\
\text { Services and Economic Development Committee, the city noted an obvious } \\
\text { economic benefit from the } 2002 \text { program: } 300 \text { jobs and } \$ 90 \text { million in venture } \\
\text { capital investment." }\end{array}$ \\
\hline \multirow{2}{*}{$\begin{array}{l}\text { Ottawa } \\
\text { Business } \\
\text { Journal } \\
(2009 \text { b) }\end{array}$} & Lead To Win 'reflects a local need' \\
\hline & $\begin{array}{l}\text { "The Lead To Win program ... takes unemployed or underemployed techies and } \\
\text { teaches them how to bring their bright idea to market - complete with the soft } \\
\text { selling skills needed for success." }\end{array}$ \\
\hline
\end{tabular}


Table 6 How sources explain Lead To Win (continued)

\begin{tabular}{|c|c|}
\hline Source & Explanation of Lead To Win \\
\hline $\begin{array}{l}\text { Ottawa } \\
\text { Business } \\
\text { Journal } \\
(2009 \mathrm{c})\end{array}$ & $\begin{array}{l}\text { "The city-funded and Carleton-University-supported Lead To Win program - } \\
\text { meant to mentor startups and generate jobs and investment for the cash-strapped } \\
\text { tech sector - has already brought in eight jobs and } \$ 920,000 \text { in just two months of } \\
\text { operation for the startups." }\end{array}$ \\
\hline $\begin{array}{l}\text { Bailetti } \\
(2010 a)\end{array}$ & $\begin{array}{l}\text { "Lead To Win is a vendor-neutral business ecosystem designed to grow creative } \\
\text { companies for the purpose of generating technology and knowledge jobs in } \\
\text { Canada's Capital Region" (p.18) }\end{array}$ \\
\hline \multirow[t]{2}{*}{$\begin{array}{l}\text { Singer and } \\
\text { Dexter } \\
(2011)\end{array}$} & $\begin{array}{l}\text { "Lead To Win for Women (LTW-W)... builds upon the existing LTW program for } \\
\text { talented individuals or teams that want to launch a new technology-based business } \\
\text { in Canada's Capital Region. The goal of LTW-W is to encourage many more } \\
\text { women in the region to start businesses and to help existing firms grow } \\
\text { substantially." (p.30) }\end{array}$ \\
\hline & $\begin{array}{l}\text { "LTW-W has four program elements. First, there is a session to help women foster } \\
\text { ideas to launch and grow businesses. Second, there is an expert speaker series that } \\
\text { encourages the development of practical knowledge for businesses. Third, there is } \\
\text { a forum for owners of established firms. Fourth, there is an outreach program for } \\
\text { college women to encourage them to start businesses." (p.30) }\end{array}$ \\
\hline $\begin{array}{l}\text { Couch } \\
(2012)\end{array}$ & $\begin{array}{l}\text { "Lead To Win [is] a free platform to help entrepreneurs. After participants develop } \\
\text { their ideas into a business opportunity, with mentoring and resources from Lead To } \\
\text { Win, they grow their business with the goal of creating six new jobs in three } \\
\text { years." }\end{array}$ \\
\hline $\begin{array}{l}\text { Symons } \\
(2012)\end{array}$ & $\begin{array}{l}\text { "Lead To Win [is] an initiative ... to help startups develop skills necessary to bring } \\
\text { their product to market. The training is free for startups who plan to bring at least } \\
\text { six jobs to the region." }\end{array}$ \\
\hline \multirow{5}{*}{$\begin{array}{l}\text { Bailetti and } \\
\text { Bot (2013) }\end{array}$} & Lead To Win is: \\
\hline & $\begin{array}{l}\text { - "an ecosystem-based job creation engine fuelled by technology entrepreneurs" } \\
\text { (p.31) }\end{array}$ \\
\hline & $\begin{array}{l}\text { - "a job-creation engine designed and operated using the ecosystem approach" } \\
\text { (p.31) }\end{array}$ \\
\hline & $\begin{array}{l}\text { - "an ecosystem that delivers services to technology entrepreneurs for the } \\
\text { purpose of creating knowledge jobs in Canada's Capital Region" (p.32) }\end{array}$ \\
\hline & $\begin{array}{l}\text { "The Lead To Win job-creation engine can be conceptualized as a collective of } \\
\text { organizations and individuals that collaborate to support the launch and growth of } \\
\text { technology ventures" (p.32) }\end{array}$ \\
\hline
\end{tabular}

From our interview and archival data we identified two representations that combine the frameworks in different ways: Lead To Win as a MSP, and Lead To Win as multilevel system. The first representation employs the MSP framework to specify the platform and its sides, and the semantic framework to specify the boundaries of the field setting. The second representation employs the platform architecture, community design, and semantic frameworks to specify and link multiple levels of analysis suggested by the codependent subsystems perspective and by prior work on architecture (Baldwin and Clark, 2000) and on reconciling the multiple frameworks (Muegge, 2013). We also explored a third representation of Lead To Win as a system of codependent subsystems linked by institutional arrangements and resource flows, but data from phase 1 was insufficient to produce a full specification comparable to prior studies such as the Muegge (2011b) and Muegge and Grant (2013) depiction of open source software 
production within the Eclipse Foundation; further development of a fully-mapped codependent subsystems perspective of Lead To Win remains a promising avenue for future work.

\subsection{Lead To Win as a MSP}

Our first representation follows from the Bailetti and Bot (2013) description of venture stakeholders interacting through a venture-creation process. Drawing on results from our interviews, Table 7 describes the participants of the ten stakeholder groups comprising the platform sides and the value of participation to each group.

Table 7 Description of Lead To Win as a MSP

\begin{tabular}{|c|c|c|c|}
\hline \multicolumn{2}{|c|}{ Side of the MSP } & \multirow{2}{*}{$\begin{array}{l}\text { Participants comprising the platform } \\
\text { side (adapted from Bailetti and Bot, } \\
\text { 2013) } \\
\text { Entrepreneurs lead the creation of } \\
\text { ventures to become leaders of the } \\
\text { startup community }\end{array}$} & \multirow{2}{*}{$\begin{array}{l}\text { Value propositions for participants } \\
\text { (themes from our interview data) } \\
\text { Wealth creation; bringing about } \\
\text { technological or social change; } \\
\text { emancipation from working for } \\
\text { others }\end{array}$} \\
\hline 1 & Entrepreneurs & & \\
\hline 2 & Implementers & $\begin{array}{l}\text { Implementers bring about and build } \\
\text { the ventures' offers; may include } \\
\text { employees, directors, advisors, and } \\
\text { contactors who have a direct financial } \\
\text { stake in the venture }\end{array}$ & $\begin{array}{l}\text { Direct financial returns through } \\
\text { payments or equity; wide range of } \\
\text { personal and professional } \\
\text { motivations also reported }\end{array}$ \\
\hline 3 & Mentors & $\begin{array}{l}\text { Mentors provide domain knowledge or } \\
\text { managerial expertise; mentors are } \\
\text { volunteers with no financial stakes in } \\
\text { the ventures they assist }\end{array}$ & $\begin{array}{l}\text { Building and maintaining networks } \\
\text { with other mentors; exchanging } \\
\text { information; building good-will. } \\
\text { Various intrinsic motivations } \\
\text { reported, including personal } \\
\text { satisfaction and a sense of either } \\
\text { 'giving back' or 'paying forward' }\end{array}$ \\
\hline 4 & $\begin{array}{l}\text { Post-secondary } \\
\text { institutions }\end{array}$ & $\begin{array}{l}\text { Universities and colleges provide } \\
\text { entrepreneurial knowledge and assets, } \\
\text { reviewers for opportunity assessments, } \\
\text { entrepreneurs, implementers, lab } \\
\text { access and research ready to } \\
\text { commercialise }\end{array}$ & $\begin{array}{l}\text { Consistent with the mission of } \\
\text { schools: enhance brand and } \\
\text { reputation in the community, attract } \\
\text { graduate students, provide } \\
\text { opportunities to students and } \\
\text { faculty }\end{array}$ \\
\hline 5 & $\begin{array}{l}\text { Service } \\
\text { providers }\end{array}$ & $\begin{array}{l}\text { Professionals provide services to } \\
\text { ventures; may include accountants, } \\
\text { lawyers, and human resources } \\
\text { providers }\end{array}$ & $\begin{array}{l}\text { Build brand and reputation; build } \\
\text { connections with future customers; } \\
\text { various intrinsic motivations }\end{array}$ \\
\hline 6 & $\begin{array}{l}\text { Business } \\
\text { partners }\end{array}$ & $\begin{array}{l}\text { Commercial entities may establish } \\
\text { operational partnerships with ventures; } \\
\text { may include channel to market } \\
\text { partners, supply chain partners, and } \\
\text { manufacturing partners }\end{array}$ & $\begin{array}{l}\text { Access to 'green' ventures that may } \\
\text { be lower risk or higher quality than } \\
\text { other early-stage ventures; build } \\
\text { connections for future } \\
\text { opportunities; potential for strategic } \\
\text { and financial returns }\end{array}$ \\
\hline
\end{tabular}


Table 7 Description of Lead To Win as a MSP (continued)

\begin{tabular}{|c|c|c|c|}
\hline \multicolumn{2}{|c|}{ Side of the MSP } & $\begin{array}{c}\text { Participants comprising the platform } \\
\text { side (adapted from Bailetti and Bot, } \\
\text { 2013) }\end{array}$ & $\begin{array}{l}\text { Value propositions for participants } \\
\text { (themes from our interview data) }\end{array}$ \\
\hline 7 & Complementors & $\begin{array}{l}\text { Providers of products and services that } \\
\text { complement the products or services } \\
\text { of ventures; complements make } \\
\text { ventures' products and services more } \\
\text { valuable to customers }\end{array}$ & $\begin{array}{l}\text { Potential for strategic and financial } \\
\text { returns }\end{array}$ \\
\hline 8 & $\begin{array}{l}\text { Economic } \\
\text { development } \\
\text { organisations }\end{array}$ & $\begin{array}{l}\text { Public and not-for-profit groups } \\
\text { provide grants and other assistance to } \\
\text { ventures, communities, and the } \\
\text { organisations that support them }\end{array}$ & $\begin{array}{l}\text { Support of policy objectives to } \\
\text { foster economic growth, job } \\
\text { creation, and entrepreneurship }\end{array}$ \\
\hline 9 & $\begin{array}{l}\text { Early buyers } \\
\text { and users }\end{array}$ & $\begin{array}{l}\text { 'Early adopters' (Rogers, 2003; } \\
\text { Moore, 1999) are willing - even eager } \\
\text { - to try and buy new products or } \\
\text { services at the earliest stages of } \\
\text { discontinuous change, providing early } \\
\text { feedback and building legitimacy for } \\
\text { the venture }\end{array}$ & $\begin{array}{l}\text { Earliest access to new products and } \\
\text { services; opportunities to influence } \\
\text { product development; opportunities } \\
\text { to innovate }\end{array}$ \\
\hline 10 & Investors & $\begin{array}{l}\text { Angel investors, angel groups, } \\
\text { strategic investors, and venture capital } \\
\text { investors provide capital to grow } \\
\text { ventures }\end{array}$ & $\begin{array}{l}\text { Access to 'green' ventures; } \\
\text { potential for high returns on } \\
\text { early-stage investment }\end{array}$ \\
\hline
\end{tabular}

In the four dimensions of the semantic framework, the MSP view of Lead To Win is:

1 a set of stakeholders

2 anchored around a process platform

3 bounded by accepting an invitation to participate

4 where participants are both organisations and individuals.

In this view, the platform is foremost a process "that guides the engagement among ecosystem members throughout the venture-creation lifecycle" [Bailetti and Bot, (2013), p.34].

\subsection{Lead To Win as a multilevel system}

Our second representation emphasises structures rather than processes. Table 8 distinguishes between three levels of analysis: things, people and organisations.

The platform in this view is comprised of technological building blocks and complementary assets that can be used and consumed to develop products, technologies, and services (Gawer, 2009; Muegge, 2013): "technology entrepreneurs whose opportunities have been rated 'green' by the Lead To Win Opportunity review board receive benefits (e.g., services) from program elements that are organized into five components. These components differ in terms of the value they add to creating jobs and the specialized knowledge required for delivering these services" [Bailetti and Bot, (2013), pp.33]. Table 9 organises the knowledge assets, resources, and services identified in our interviews into these five components. 
Table 8 Description of Lead To Win structures at three levels of organisation

\begin{tabular}{|c|c|c|c|c|}
\hline $\begin{array}{l}\text { Level of } \\
\text { organisation }\end{array}$ & Structure & Framework & Property & Lead To Win \\
\hline \multirow{4}{*}{$\begin{array}{l}\text { Organisation } \\
\text { of economic } \\
\text { actors }\end{array}$} & \multirow{4}{*}{$\begin{array}{l}\text { Lead To } \\
\text { Win } \\
\text { ecosystem }\end{array}$} & \multirow[t]{4}{*}{$\begin{array}{l}\text { Muegge } \\
\text { (2011a) }\end{array}$} & $\begin{array}{l}\text { Conceptual } \\
\text { location }\end{array}$ & A network of organisations \\
\hline & & & Anchor & $\begin{array}{l}\text { The Lead To Win platform, comprised of } \\
\text { processes, services and assets }\end{array}$ \\
\hline & & & Boundaries & $\begin{array}{l}\text { Acceptance of an invitation to participate; } \\
\text { ventures are invited to participate if the } \\
\text { entrepreneur receives a 'green' rating from } \\
\text { a presentation to an opportunity review } \\
\text { panel; organisations may be invited to } \\
\text { participate and contribute by the Lead To } \\
\text { Win Council }\end{array}$ \\
\hline & & & Elements & $\begin{array}{l}\text { Organisations that employ the individuals } \\
\text { that comprise the Lead To Win community } \\
\text { and contribute to the Lead To Win } \\
\text { platform; includes not-for-profits, public } \\
\text { institutions, and for-profit businesses }\end{array}$ \\
\hline \multirow[t]{4}{*}{$\begin{array}{l}\text { Organisation } \\
\text { of people }\end{array}$} & \multirow[t]{4}{*}{$\begin{array}{l}\text { Lead To } \\
\text { Win } \\
\text { community }\end{array}$} & \multirow[t]{4}{*}{$\begin{array}{l}\text { West and } \\
\text { O’Mahony } \\
\text { (2008) }\end{array}$} & Production & $\begin{array}{l}\text { Voluntary contributions of time, expertise, } \\
\text { funds, and resources by members of the } \\
\text { community and ecosystem }\end{array}$ \\
\hline & & & Governance & $\begin{array}{l}\text { Membership in the Lead To Win Council } \\
\text { is by invitation based on merit and } \\
\text { contribution }\end{array}$ \\
\hline & & & $\begin{array}{l}\text { Intellectual } \\
\text { property }\end{array}$ & $\begin{array}{l}\text { Some community output is open access } \\
\text { (available to all); most services are 'club } \\
\text { goods' available to ventures that receive a } \\
\text { 'green' rating; some services have } \\
\text { additional requirements for access }\end{array}$ \\
\hline & & & & $\begin{array}{l}\text { Lead To Win makes no claims on the IP of } \\
\text { ventures }\end{array}$ \\
\hline \multirow[t]{4}{*}{$\begin{array}{l}\text { Organisation } \\
\text { of things }\end{array}$} & \multirow{4}{*}{$\begin{array}{l}\text { Lead To } \\
\text { Win } \\
\text { platform }\end{array}$} & \multirow{4}{*}{$\begin{array}{l}\text { Baldwin } \\
\text { and Clark } \\
\quad(2000 \\
2006)\end{array}$} & \multirow[t]{2}{*}{ Modularity } & $\begin{array}{l}\text { High modularity in use: entrepreneurs can } \\
\text { combine program elements as desired }\end{array}$ \\
\hline & & & & $\begin{array}{l}\text { High modularity in design: organisers can } \\
\text { add or remove elements or reconfigure } \\
\text { existing elements to create new programs }\end{array}$ \\
\hline & & & \multirow[t]{2}{*}{$\begin{array}{l}\text { Option } \\
\text { value }\end{array}$} & $\begin{array}{l}\text { High option value in use: entrepreneurs } \\
\text { can access valuable program elements but } \\
\text { are not required to do so }\end{array}$ \\
\hline & & & & $\begin{array}{l}\text { High option value in design: organisers } \\
\text { can develop new elements or expand } \\
\text { existing elements in response to the } \\
\text { availability of new funds or interest from } \\
\text { entrepreneurs, but are under no obligation } \\
\text { to do so }\end{array}$ \\
\hline
\end{tabular}


Table 9 Lead To Win program categories and examples of program elements

\begin{tabular}{|c|c|c|c|}
\hline \multicolumn{2}{|c|}{$\begin{array}{l}\text { Program } \\
\text { category }\end{array}$} & \multirow[t]{2}{*}{$\begin{array}{l}\text { Program } \\
\text { element }\end{array}$} & \multirow{2}{*}{$\begin{array}{l}\text { Description } \\
\text { Workspace is provided to qualified entrepreneurs. Lead To } \\
\text { Win does not own buildings; it rents space or accesses space } \\
\text { provided by partner organisations in the Lead To Win } \\
\text { ecosystem. }\end{array}$} \\
\hline 1 & Workspace & & \\
\hline \multirow[t]{4}{*}{2} & $\begin{array}{l}\text { Knowledge: } \\
\text { advice, } \\
\text { training, } \\
\text { assessment, } \\
\text { and } \\
\text { networking }\end{array}$ & $\begin{array}{l}\text { Opportunity } \\
\text { assessments }\end{array}$ & $\begin{array}{l}\text { To gain access to most Lead To Win services, entrepreneurs } \\
\text { first present to a panel of external reviewers from the local } \\
\text { business community. The panel ranks each opportunity as } \\
\text { green, yellow, or red, and provides feedback. 'Green' } \\
\text { opportunities are invited to join 'phase 2' of Lead To Win } \\
\text { and to access other Lead To Win services. }\end{array}$ \\
\hline & & Boot camp & $\begin{array}{l}\text { Six days of presentations, workshops, and learning exercises } \\
\text { designed to convey knowledge, develop skills, and advance } \\
\text { the business. An opportunity assessment immediately } \\
\text { follows the boot camp. }\end{array}$ \\
\hline & & $\begin{array}{l}\text { TIM Lecture } \\
\text { Series }\end{array}$ & $\begin{array}{l}\text { A series of interactive public talks organised by the teaching } \\
\text { faculty of Carleton University's Technology Innovation } \\
\text { Management program. }\end{array}$ \\
\hline & & Partner events & $\begin{array}{l}\text { Workshops and other events delivered jointly with partner } \\
\text { organisations in the Lead To Win ecosystem. }\end{array}$ \\
\hline \multirow[t]{5}{*}{3} & $\begin{array}{l}\text { Business } \\
\text { development } \\
\text { service and } \\
\text { expertise }\end{array}$ & Invest desk & $\begin{array}{l}\text { Educates, trains, and coaches founders regarding external } \\
\text { investment; facilitates fundraising for companies ready for } \\
\text { external investment; assists founders to define and refine a } \\
\text { list of target investors. }\end{array}$ \\
\hline & & $\begin{array}{c}\text { Develop } \\
\text { business desk }\end{array}$ & $\begin{array}{l}\text { Educates, trains, monitors, coaches, and advises founders on } \\
\text { how to grow their business; assists founders to define and } \\
\text { refine a list of target business relationships and the } \\
\text { development of business pitches. }\end{array}$ \\
\hline & & Sales desk & $\begin{array}{l}\text { Educates, trains, monitors, and coaches founders on how to } \\
\text { improve the success of their customer sales engagements; } \\
\text { helps founders define and refine the list of prospect } \\
\text { customers, develop call scripts, make cold calls, form new } \\
\text { relationships, and strengthen existing relationships; helps } \\
\text { founders to close sales. }\end{array}$ \\
\hline & & Progress desk & $\begin{array}{l}\text { Manage reviews that ensure companies meet growth } \\
\text { milestones; collects and maintains data; removes } \\
\text { non-performers that fail to maintain 'green' status; assists } \\
\text { founders to meet milestones. }\end{array}$ \\
\hline & & Global desk & $\begin{array}{l}\text { Educates, trains, and coaches founders and stakeholders to } \\
\text { launch and grow ventures that are global from inception. }\end{array}$ \\
\hline \multirow[t]{2}{*}{4} & Funding & $\begin{array}{l}\text { Graduate } \\
\text { Enterprise } \\
\text { Internships } \\
\quad(\mathrm{GEI})\end{array}$ & $\begin{array}{l}\text { Program to pay salaries of graduate student interns who } \\
\text { work for entrepreneurs. }\end{array}$ \\
\hline & & Global Start & $\begin{array}{l}\text { Program to fund and support businesses that are global from } \\
\text { inception. }\end{array}$ \\
\hline
\end{tabular}


Table 9 Lead To Win program categories and examples of program elements (continued)

\begin{tabular}{|c|c|c|c|}
\hline \multicolumn{2}{|c|}{$\begin{array}{l}\text { Program } \\
\text { category }\end{array}$} & $\begin{array}{c}\text { Program } \\
\text { element }\end{array}$ & Description \\
\hline & \multirow{7}{*}{$\begin{array}{l}\text { Strategic } \\
\text { assets }\end{array}$} & $\begin{array}{l}\text { Ottawa Young } \\
\text { Entrepreneurs } \\
\quad(\text { OYE) }\end{array}$ & $\begin{array}{l}\text { Program to fund and support nascent entrepreneurs at } \\
\text { Ottawa-area universities and colleges; sponsored by Ontario } \\
\text { Centres of Excellence. }\end{array}$ \\
\hline & & $\begin{array}{l}\text { Nicol } \\
\text { Entrepreneurial } \\
\text { Institute }\end{array}$ & $\begin{array}{l}\text { Program to fund and mentor student entrepreneurs; } \\
\text { sponsored by a private endowment (Ottawa Business } \\
\text { Journal, 2011). }\end{array}$ \\
\hline & & VentureStart & $\begin{array}{l}\text { Program to fund and mentor qualified entrepreneurs in the } \\
\text { science, technology, engineering, and math fields in } \\
\text { Southern Ontario; sponsored by a partnership of } \\
\text { not-for-profit groups (Symons, 2012). }\end{array}$ \\
\hline & & $\begin{array}{l}\text { Network of } \\
\text { mentors, faculty } \\
\text { and reviewers }\end{array}$ & $\begin{array}{l}\text { Providers of specialised and individual coaching and } \\
\text { expertise. }\end{array}$ \\
\hline & & $\begin{array}{l}\text { Technology } \\
\text { Innovation } \\
\text { Management } \\
\text { Review }\end{array}$ & $\begin{array}{l}\text { Peer-reviewed open access journal on technology innovation } \\
\text { management published by Carleton University } \\
\text { (http://timreview.ca). }\end{array}$ \\
\hline & & $\begin{array}{l}\text { Theses and } \\
\text { projects }\end{array}$ & $\begin{array}{l}\text { Graduate student research undertaken within Carleton } \\
\text { University's Technology Innovation Management program } \\
\text { (http://timprogram.ca). }\end{array}$ \\
\hline & & BigBlueButton & $\begin{array}{l}\text { Web conferencing system for remote learning and distance } \\
\text { education. }\end{array}$ \\
\hline
\end{tabular}

We know of no way to quantitatively measure the modularity or option value of the Lead To Win platform; nonetheless, we argue qualitatively that both measures are high for entrepreneurs and organisers. Entrepreneurs who have received a 'green' rating may flexibly choose, consume, and combine components and elements (implying high modularity-in-use) when and if a service is most valuable (implying high option value-in-use). In our case data, for example, several founders benefitted from sales desk help with early customer contracts. Other examples from the case data imply high modularity-in-design and high option value-in-design. For example, organisers added new elements in response to stakeholder needs and reconfigured existing elements to create new specialised variants such as Lead To Win For Women (Singer and Dexter, 2011), Carleton Entrepreneurs and Global Start.

The Lead To Win community is the "voluntary group of people with common interests and a shared sense of identity" (Muegge, 2013) that maintains and extends the platform through contributions of time, expertise, funds, and resources. Decisions are made by the organisers, especially the Lead To Win Council (Bailetti and Bot, 2013), which plans events and invites members of the community to participate. Much community output is open access (Willinsky, 2009) including training material distributed under Creative Commons licenses (http://creativecommons.org). Other community output is club goods (Buchanan, 1965; Sandler and Tschirhart, 1997) accessible to entrepreneurs rated 'green'. Lead To Win makes no claims on IP of entrepreneurs, however some choose to donate assets to the platform. 
In the four dimensions of the semantic framework, the multilevel system view of Lead To Win is:

1 a level of organisation

2 anchored around a platform of services and assets

3 bounded by accepting an invitation to participate

4 where participants are organisations employing individuals that comprise the Lead To Win community.

\section{Results of phase 2: case studies of new ventures}

\subsection{Case selection}

We selected six cases of companies that had been operating for at least two years and had experienced business model change. Purposive sampling (Yin, 2011) enabled replication within groups of cases and variation between groups of cases. For example, two cases had founders who completed graduate degrees in Technology Innovation Management from Carleton University while growing their businesses; four cases did not. Two cases participated in Global Start, a specialised program within Lead To Win; four cases did not. Three cases comprise a single company; three cases comprise two or more companies by the same founder. Some case companies raised substantial equity investment while others 'bootstrapped' from early profits. One founder joined in 2002 with the first cohort; five joined after the re-launch in 2009. Some founders enjoyed lucrative exits, including a successful acquisition; others remain with their companies, and others experienced less lucrative exits.

We refer to each case by a designated label, Case A through Case F, sequenced in the order in which the founders joined Lead To Win. As with prior case study research published in top journals (e.g., Brown and Eisenhardt, 1997; Bingham and Eisenhardt, 2011; Davis and Eisenhardt, 2011; Hallen and Eisenhardt, 2012), we provide anonymity to companies and respondents. Our rationale was two-fold: to encourage greater disclosure of information about new venture business models, and to reduce the threat of social desirability bias (Nederhof, 1985) that might otherwise favour positive reports by respondents.

\subsection{Business models}

We developed a simple rule to distinguish between different business models within a case. For our purposes, a business model consists of either a stable configuration of the four business model components or a period of ferment and search where some components are stable and one or more components vary through bounded experimentation. A transition between business models occurs either when either one or more components change from a stable configuration or when the pattern of experimentation changes to either a new pattern or a stable configuration. 
Figure 1 is a timeline of business models and significant events for each case. The horizontal axis is time measured in years. Shaded rectangles are business models; there may one or multiple business models at any point in time. Diamonds (founders joining Lead To Win) or triangles (launching or exiting a venture) mark significant events. Within each case, we number business models sequentially. For example, 'A1' is the first business model of Case A, and 'B2' is the second business model of Case B. Business models within the same row are transitions within a venture. For example, Company B operates with business model B1 from approximately 2003 through 2008, then transitions to business model B2 in 2009, then to business model B3 in 2013. Business models within different rows of the same case are different new ventures. For example, the founder of Case $\mathrm{C}$ launched one company in 2009 with business model $\mathrm{C} 1$, then launched a second company in 2011 with business model C2 while continuing to operate the first company.

Figure 1 Timeline (see online version for colours)

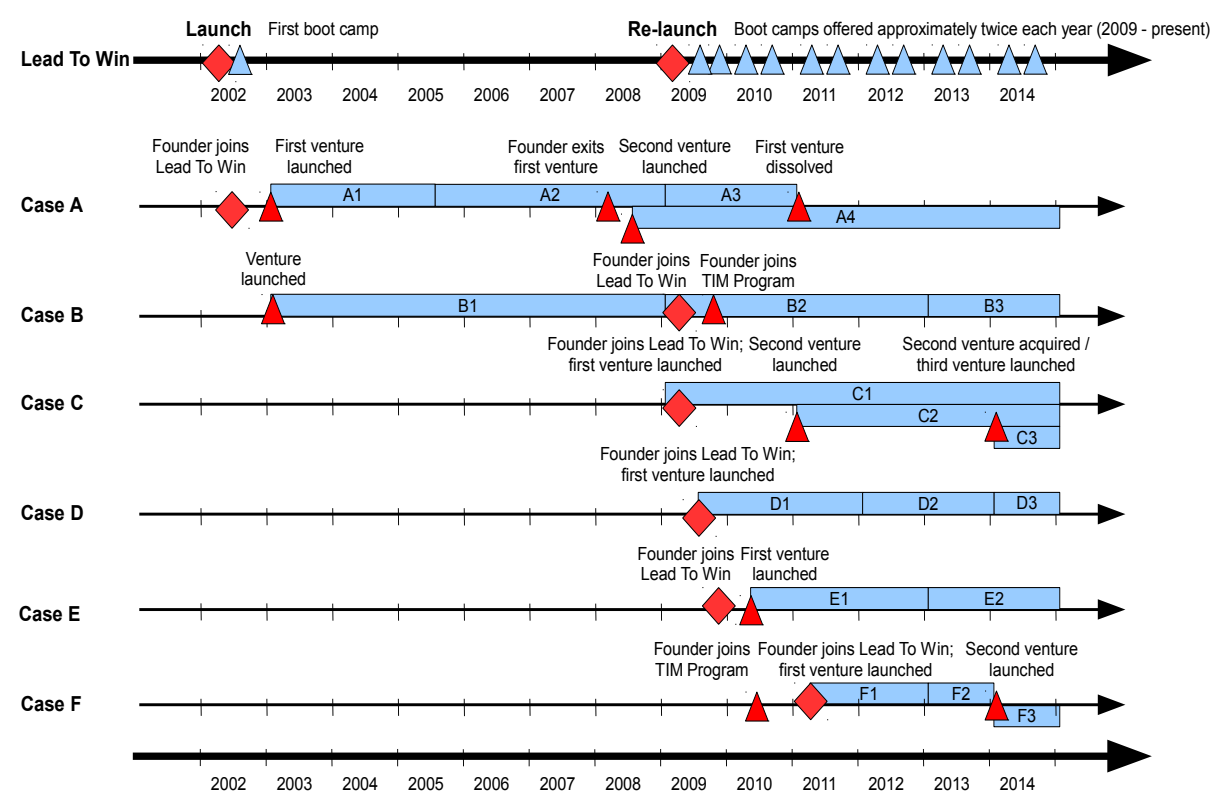

\subsection{Participation}

Table 10 reports case participation in the categories and elements previously described in Table 9. Table 11 ranks the elements from most to least participation.

\subsection{Benefits of participation}

We identified five emergent themes on benefits of participation: new business skills and knowledge, grants and assistance with grant applications and raising investment, improved credibility with stakeholders, business development, and stronger relationship and networks. 
Table 10 Case participation in Lead To Win program elements

\begin{tabular}{|c|c|c|c|c|c|c|c|c|}
\hline \multicolumn{2}{|c|}{ Program category } & \multirow{2}{*}{$\frac{\text { Program element }}{\text { Offices }}$} & \multirow[t]{2}{*}{$A$} & \multirow[t]{2}{*}{$B$} & \multirow[t]{2}{*}{$C$} & \multirow{2}{*}{$\frac{D}{\bullet}$} & \multirow{2}{*}{$\begin{array}{l}E \\
\bullet\end{array}$} & \multirow{2}{*}{$\begin{array}{l}F \\
\bullet\end{array}$} \\
\hline 1 & Workspace & & & & & & & \\
\hline \multirow[t]{4}{*}{2} & Knowledge & Opportunity assessments (required) & • & • & $\cdot$ & • & $\bullet$ & $\bullet$ \\
\hline & & Boot camp & • & • & • & • & • & • \\
\hline & & TIM Lecture Series & • & • & - & & & \\
\hline & & Partner events & • & • & • & $\bullet$ & • & • \\
\hline \multirow[t]{2}{*}{3} & Business & Invest desk & • & • & • & • & • & • \\
\hline & development & Sales Desk & & & - & & & • \\
\hline \multirow[t]{5}{*}{4} & Funding & Graduate Enterprise Internships (GEI) & & & & • & • & • \\
\hline & & Global Start & & & - & & • & \\
\hline & & Ottawa Young Entrepreneurs (OYE) & & • & & & & $\bullet$ \\
\hline & & Nicol Entrepreneurial Institute & & & & & & • \\
\hline & & VentureStart & & & & • & • & \\
\hline \multirow[t]{3}{*}{5} & Strategic & Network of mentors, faculty, and reviewers & • & • & • & • & • & • \\
\hline & & Technology Innovation Management Review & • & $\bullet$ & & & & $\bullet$ \\
\hline & & Theses and projects & & • & & & • & $\bullet$ \\
\hline
\end{tabular}

Table 11 Program elements, ranked by number of participating case companies

\begin{tabular}{lc}
\hline Program element & Count of participating cases \\
\hline Boot camp & 6 \\
Invest desk & 6 \\
Network of mentors, faculty, and reviewers & 6 \\
Opportunity assessments & 6 \\
Partner events & 6 \\
Graduate Enterprise Internships (GEI) & 3 \\
Technology Innovation Management Review & 3 \\
Theses and projects & 3 \\
TIM Lecture Series & 3 \\
Workspace & 3 \\
Global Start & 2 \\
Ottawa Young Entrepreneurs (OYE) & 2 \\
Sales desk & 2 \\
VentureStart & 2 \\
Nicol Entrepreneurial Institute & 1 \\
\hline
\end{tabular}




\section{Results of phase 3: propositions and theory-building}

\subsection{Variables}

We began the theory-building phase by developing case-level variables, operational measures and decision rules for assigning values to cases. Five variables were ultimately useful for building propositions. The first variable, which became the independent variable of our propositions, measures ecosystem participation.

Intensity of participation: Participation in some components of Lead To Win requires a relatively greater commitment of time, effort, and other resources by the entrepreneur. We conceptualise the entrepreneur's commitment as intensity of participation. For example, attending partner events is relatively low intensity, requiring approximately three hours of the entrepreneur's time. In contrast, enrolling in the Technology Innovation Management program is relatively high intensity: students commit to hundreds of hours of work over a time period of 18 to 24 months, completion of challenging graduate courses and a research thesis or project, and the payment of tuition fees, to earn a graduate degree in engineering.

Table 12 Participation intensity

\begin{tabular}{|c|c|c|}
\hline Case & $\begin{array}{c}\text { Intensity of } \\
\text { participation }\end{array}$ & Rationale: most intense ways in which the founder participated \\
\hline A & High (3) & $\begin{array}{l}\text { Participated in the re-launch of Lead To Win in 2009; volunteered as a } \\
\text { faculty member of the boot camp, interviewer at intake assessments, } \\
\text { and reviewer of opportunity assessments; published as co-author with } \\
\text { TIM faculty; published an article in the Technology Innovation } \\
\text { Management Review; delivered a public talk in the TIM Lecture Series. }\end{array}$ \\
\hline B & High (3) & $\begin{array}{l}\text { Joined the TIM program (after joining Lead To Win), wrote and } \\
\text { defended a graduate thesis, and earned a Master of Applied Science } \\
\text { degree; published as a co-author with TIM faculty; published multiple } \\
\text { articles in the Technology Innovation Management Review; participated } \\
\text { as a speaker at a public talk in the TIM Lecture Series. }\end{array}$ \\
\hline $\mathrm{C}$ & Medium (2) & $\begin{array}{l}\text { Joined the Global Start program; participated as a speaker at a public } \\
\text { talk in the TIM Lecture Series. }\end{array}$ \\
\hline $\mathrm{D}$ & Low (1) & $\begin{array}{l}\text { Joined the VentureStart program; employed a graduate student through } \\
\text { the Graduate Enterprise Internship program. }\end{array}$ \\
\hline $\mathrm{E}$ & Medium (2) & $\begin{array}{l}\text { Joined the Global Start program; sponsored a graduate research project } \\
\text { in the TIM program; employed a graduate student through the Graduate } \\
\text { Enterprise Internship program. }\end{array}$ \\
\hline $\mathrm{F}$ & High (3) & $\begin{array}{l}\text { Joined the TIM program (prior to joining Lead To Win), wrote a } \\
\text { graduate project, and earned a Master of Engineering degree; published } \\
\text { multiple articles in the Technology Innovation Management Review; } \\
\text { employed a graduate student through the Graduate Enterprise Internship } \\
\text { program. }\end{array}$ \\
\hline
\end{tabular}

We specify the intensity of participation of each case using a three-point ordinal scale of high (3), medium (2) and low (1). Table 10 from Section 6.3 provides the source material about participation. We assign the value high (3) to cases where a founder participated in the most intense activities, such as joining the TIM program, publishing with TIM faculty, and participating in the organisation and delivery of Lead To Win. We assign the value medium (2) to cases that do not meet the criteria for high participation, but did 
become involved in moderate intensity activities such as the Global Start program, presenting at the TIM lecture series, and sponsoring a TIM research project. We assign the value low (1) to all other cases. Table 12 reports the participation intensity and rationale for each case.

We developed three case-level business model variables: business model differentiation, business model sophistication, and extent of change to business models over time. The source material to assign values to the business model variables is the business model timeline (Figure 1, Section 6.2) and business model specifications from case reports.

Differentiation of business models: business model innovation can vary greatly between firms (Chesbrough, 2006; Teece, 2009). Some business models are similar to those of competitors. Others can be differentiating, novel, or even 'game changing' (Johnson et al., 2008). We conceptualise this notion as business model differentiation, where differentiation is the extent to which a business model differs from the models of competitors.

We specify business model differentiation at two levels of analysis: business model and case. At the business model level, we specify differentiation using a three-point ordinal scale of high (3), medium (2) and low (1). We compare the four components of a focal business model against the four components of competitor business models and count the number of components that differ. We assign the value high (3) to differentiated models where three or four components differ significantly from those of competitors. We assign the value medium (2) to somewhat differentiated models where two components differ. We assign the value low (1) to all other business models - that is, imitative business models with one or zero components that differ from those of competitors. At the case level, we specify differentiation using a two-point ordinal scale of high (2) and low (1). We assign the value high (2) to cases with at least one business model of high differentiation or at least two models with medium differentiation. We assign the value low (1) to all other cases, that is, cases with no business models of high differentiation and no more than one business model of medium differentiation.

Sophistication of business models: business models vary with respect to the ease in which they can be explained, illustrated, and understood. We conceptualise this notion as business model sophistication.

Hagiu (2007) distinguishes between merchant models where a supplier sells a well-defined product to a well-defined customer segment and two-sided platform models that bring together two groups of stakeholders where either or both groups could be considered customers. Similarly, Bailetti (2010b) distinguishes between traditional business models where a supplier sells products to customers and business ecosystem models where a supplier uses a multi-sided platform to interact with multiple stakeholder groups to develop and market its offers. For both Hagiu (2007) and Bailetti (2010b), the second form of business model is more sophisticated than the first.

We specify sophistication at two levels of analysis: business model and case. At the business model level, we specify sophistication using a two-point ordinal scale of high (2) and low (1). We assign the value high (2) to business models anchored around a MSP or business ecosystem. We assign the value low (1) to all other business models without a MSP or business ecosystem, including merchant models and traditional models. At the case level, we specify sophistication using a two-point ordinal scale of high (2) and low (1). We assign the value high (2) to cases with at least one business model of high 
sophistication. We assign the value of low (1) to cases with no business models of high sophistication. Table 13 reports differentiation and sophistication for each case.

Table 13 Business model differentiation and sophistication

\begin{tabular}{|c|c|c|c|c|}
\hline $\begin{array}{l}\text { Case or } \\
\text { business } \\
\text { model }\end{array}$ & Differentiation & $\begin{array}{l}\text { Rationale: differentiated } \\
\text { business model components }\end{array}$ & Sophistication & $\begin{array}{l}\text { Rationale: } \text { MSP or } \\
\text { ecosystem }\end{array}$ \\
\hline A1 & Medium (2) & $\begin{array}{l}\text { Novel SVPs and cost structure } \\
\text { in an established market }\end{array}$ & Low (1) & Merchant ; traditional \\
\hline $\mathrm{A} 2$ & Medium (2) & $\begin{array}{l}\text { Pivot to an untapped customer } \\
\text { segment }\end{array}$ & Low (1) & Merchant; traditional \\
\hline A3 & Low (1) & $\begin{array}{l}\text { Pivot to a mature customer } \\
\text { segment }\end{array}$ & Low (1) & Merchant; traditional \\
\hline A4 & High (3) & $\begin{array}{l}\text { New business model with high } \\
\text { novelty, addressing a new } \\
\text { untapped market }\end{array}$ & High (2) & Multi-sided platform \\
\hline Case A & High (2) & $\begin{array}{l}\text { Business models A1 and A2 } \\
\text { are medium and A4 is high } \\
\text { differentiation; overall } \\
\text { differentiation is therefore high }\end{array}$ & High (2) & $\begin{array}{l}\text { Business model A4 is } \\
\text { high sophistication; } \\
\text { overall is therefore } \\
\text { high }\end{array}$ \\
\hline B1 & Low (1) & $\begin{array}{l}\text { Undifferentiated consulting } \\
\text { model }\end{array}$ & Low (1) & Merchant; traditional \\
\hline B2 & Low (1) & $\begin{array}{l}\text { Undifferentiated licensing } \\
\text { model }\end{array}$ & Low (1) & Merchant; traditional \\
\hline B3 & High (3) & $\begin{array}{l}\text { Ecosystem model with high } \\
\text { novelty }\end{array}$ & High (2) & Business ecosystem \\
\hline Case B & High (2) & B3 is high differentiation & High (2) & $\begin{array}{l}\text { B3 is high } \\
\text { sophistication }\end{array}$ \\
\hline $\mathrm{C} 1$ & Low (1) & $\begin{array}{l}\text { Undifferentiated consulting } \\
\text { model }\end{array}$ & Low (1) & Merchant; traditional \\
\hline $\mathrm{C} 2$ & Low (1) & $\begin{array}{l}\text { Second venture addresses an } \\
\text { underserved regional market; } \\
\text { one component differs from } \\
\text { competition }\end{array}$ & Low (1) & Merchant; traditional \\
\hline C3 & Low (1) & $\begin{array}{l}\text { Third venture addresses an } \\
\text { underserved segment; one } \\
\text { components differs }\end{array}$ & Low (1) & Merchant; traditional \\
\hline Case C & Low (1) & $\begin{array}{l}\text { All models are low } \\
\text { differentiation }\end{array}$ & Low (1) & $\begin{array}{l}\text { All models are low } \\
\text { sophistication }\end{array}$ \\
\hline
\end{tabular}


Table 13 Business model differentiation and sophistication (continued)

\begin{tabular}{|c|c|c|c|c|}
\hline $\begin{array}{l}\text { Case or } \\
\text { business } \\
\text { model }\end{array}$ & Differentiation & $\begin{array}{l}\text { Rationale: differentiated } \\
\text { business model components }\end{array}$ & Sophistication & $\begin{array}{l}\text { Rationale: } \text { MSP or } \\
\text { ecosystem }\end{array}$ \\
\hline D1 & Low (1) & $\begin{array}{l}\text { Novel customer value } \\
\text { proposition for a specialised } \\
\text { niche segment; one component } \\
\text { differs from competition }\end{array}$ & Low (1) & Merchant; traditional \\
\hline D2 & Medium (2) & $\begin{array}{l}\text { Added new customer segment } \\
\text { with novel pricing and cost } \\
\text { structure; two components } \\
\text { differ from competition }\end{array}$ & Low (1) & Merchant; traditional \\
\hline D3 & Low (1) & Added new customer segment & Low (1) & Merchant; traditional \\
\hline Case D & Low (1) & $\begin{array}{l}\text { All models are low or medium } \\
\text { differentiation; fewer than two } \\
\text { medium }\end{array}$ & Low (1) & $\begin{array}{l}\text { All models are low } \\
\text { sophistication }\end{array}$ \\
\hline E1 & Medium (2) & $\begin{array}{l}\text { Differentiated customer value } \\
\text { proposition and novel } \\
\text { capabilities }\end{array}$ & Low (1) & Merchant; traditional \\
\hline E2 & High (3) & $\begin{array}{l}\text { Active search and } \\
\text { experimentation; explored } \\
\text { differentiation in all } \\
\text { components }\end{array}$ & Low (1) & Merchant; traditional \\
\hline E3 & High (3) & $\begin{array}{l}\text { Narrow focus; three } \\
\text { components differ }\end{array}$ & Low (1) & Merchant; traditional \\
\hline Case E & High (3) & $\begin{array}{l}\text { E2 and E3 are high } \\
\text { differentiation }\end{array}$ & Low (1) & $\begin{array}{l}\text { All models are low } \\
\text { sophistication }\end{array}$ \\
\hline $\mathrm{F} 1$ & Medium (2) & $\begin{array}{l}\text { Novel problem space and } \\
\text { SVPs; active search }\end{array}$ & High (2) & Multi-sided platform \\
\hline $\mathrm{F} 2$ & High (3) & $\begin{array}{l}\text { Pivot to new value } \\
\text { propositions and profit formula } \\
\text { enabled by novel capabilities }\end{array}$ & High (2) & Multi-sided platform \\
\hline F3 & Medium (2) & $\begin{array}{l}\text { Pivot to a different problem } \\
\text { space; two components differ } \\
\text { from competition; active } \\
\text { search }\end{array}$ & High (2) & Multi-sided platform \\
\hline Case F & High (3) & $\begin{array}{l}\text { F2 is high differentiation; } \\
\text { F1 and F3 are medium } \\
\text { differentiation }\end{array}$ & High (2) & $\begin{array}{l}\text { All models are high } \\
\text { sophistication }\end{array}$ \\
\hline
\end{tabular}

Extent of business model change: Changes in business model components may lead to a better business model over time (Chesbrough and Rosenbloom, 2002). We conceptualise potential for learning and discovery through business model transformation as extent of change.

We specify extent of business model change using a three-point ordinal scale of high (3), medium (2) and low (1). At each business model transition, we count the number of changed components - one, two, three or four - then compute the sum. We then map that sum to the three-point ordinal scale by assigning the value high (3) to cases where business model components changed more than six times, medium (2) to cases where 
business model components changed exactly six times, and low (1) to cases where business model components changed fewer than six times. Table 14 reports the extent of change and rationale for each case, and the fourth, fifth, and sixth columns report the number of years over which the changes occurred, the mean time for a component change, and the mean number of component changes per year, respectively.

Table 14 Extent of business model changes and breadth of benefits reported

\begin{tabular}{lccccccc}
\hline Case & $\begin{array}{c}\text { Rationale: } \\
\text { count of } \\
\text { change } \\
\text { business } \\
\text { model } \\
\text { components } \\
\text { changed }\end{array}$ & $\begin{array}{c}\text { Time } \\
\text { period } \\
\text { (years) }\end{array}$ & $\begin{array}{c}\text { Mean time } \\
\text { component } \\
\text { change } \\
\text { (years) }\end{array}$ & $\begin{array}{c}\text { Rate of change } \\
\text { (changes/year) }\end{array}$ & $\begin{array}{c}\text { Rationale: } \\
\text { Benefits of }\end{array}$ & $\begin{array}{c}\text { count of } \\
\text { benefits } \\
\text { categories } \\
\text { reported }\end{array}$ \\
\hline A & High (3) & 8 & 12 & 1.5 & 0.6 & High (3) & 5 \\
B & Medium (2) & 6 & 11 & 1.8 & 0.5 & High (3) & 5 \\
C & Low (1) & 5 & 6 & 1.2 & 0.8 & High (3) & 5 \\
D & Medium (2) & 6 & 6 & 1.0 & 1.0 & Medium (2) & 4 \\
E & High (3) & 7 & 6 & 1.0 & 1.0 & Medium (2) & 4 \\
F & High (3) & 8 & 4 & 0.5 & 2.0 & High (3) & 5 \\
\hline
\end{tabular}

Finally, we developed one variable to assess the ways in which a company benefits from participation in the ecosystem.

Breadth of benefits of participation: we conceptualise the range of benefits reported by founders as the breadth of benefits of participation.

We specify the breadth of benefits using a two-point ordinal scale of high (2) and medium (1). We assign the value of high (2) to cases where founders self-reported benefits in all five benefit categories reported in section 6.4. We assign the value of medium (1) to cases where founders self-reported benefits in four or fewer categories. All cases reported benefits in at least four categories, so the range of this variable is small. Table 14 also reports the breadth of benefits and rationale for each case.

\subsection{Associations}

Table 15 summarises the case results with intensity of participation as a possible independent variable, sequenced high to low. From these results, we induce four propositions.

Table 15 Case results sorted by intensity of participation

\begin{tabular}{lccccc}
\hline $\begin{array}{l}\text { Intensity of } \\
\text { participation }\end{array}$ & Case & $\begin{array}{c}\text { Business } \\
\text { model novelty }\end{array}$ & $\begin{array}{c}\text { Business model } \\
\text { sophistication }\end{array}$ & $\begin{array}{c}\text { Extent of business } \\
\text { model change }\end{array}$ & $\begin{array}{c}\text { Breadth of } \\
\text { benefits }\end{array}$ \\
\hline High (3) & A & High (2) & High (2) & High (3) & High (3) \\
High (3) & B & High (2) & High (2) & Medium (2) & High (3) \\
High (3) & F & High (2) & High (2) & High (3) & High (3) \\
Medium (2) & C & Low (1) & Low (1) & Low (1) & High (3) \\
Medium (2) & E & High (2) & Low (1) & High (3) & Medium (2) \\
Low (1) & D & Low (1) & Low (1) & Medium (2) & Medium (2) \\
\hline
\end{tabular}


At the highest intensity of participation, all three cases (A, B and F) have high business model differentiation. At the lowest intensity of participation, case $\mathrm{D}$ has low differentiation. At medium intensity of participation, case $\mathrm{C}$ has high differentiation and case $\mathrm{E}$ has low differentiation; for a two-state variable this is an intermediate result, with the average of the two cases between high and low. We therefore propose a positive relationship between intensity of participation and business model differentiation.

Proposition 1 Higher intensity of participation is associated with higher business model differentiation.

At the highest intensity of participation, all three cases (A, B and F) have high business model sophistication. At medium and low intensity of participation, all three cases (C, D, and E) have low sophistication. We therefore propose a positive relationship between intensity of participation and business model sophistication.

Proposition 2 Higher intensity of participation is associated with higher business model sophistication.

At the highest intensity of participation, two of the three cases (A and F) have high extent of business model change and one case (B) has medium extent of change. At the lowest intensity of participation, case $\mathrm{D}$ has medium extent of change. At medium intensity of participation, case $\mathrm{E}$ has high intensity and case $\mathrm{C}$ has low intensity; the average for the category is below that of the highest participation category and similar to that of the lowest participation category. We therefore propose a positive relationship between intensity of participation and extent of business model change.

Proposition 3 Higher intensity of participation is associated with more extensive business model change.

At the highest intensity of participation, all three cases (A, B and F) have high breath of benefits of participation. At the lowest intensity of participation, case D has medium benefits of participation. At medium intensity of participation, case $\mathrm{C}$ has high breadth of benefits and case $\mathrm{E}$ has medium breadth of benefits; the average for the category is between medium and high. We therefore propose a positive relationship between intensity of participation and benefits of participation.

Proposition 4 Higher intensity of participation is associated with higher breadth of benefits of participation.

\section{Discussion}

Our main contribution is a preliminary answer to our research question: How does new venture participation in a business ecosystem impact new venture business models?

From our literature review and conceptual work, we argued that participation in a business ecosystem is likely to impact new venture business models and we identified possible connections. Consistent with Teece (2009, 2010), Zott and Amit (2013) and Muegge (2013), we situate the business model and the business ecosystem constructs at different levels of analysis. New ventures that participate in a business ecosystem thus develop their business model within the context of that ecosystem. As in organisation theory (Scott and Davis, 2007), strategy (Mintzberg et al., 1998) and marketing 
(Simmons et al., 2013), we expect context to similarly shape business model discovery (Muegge, 2012). We identified possible connections between the two levels of analysis, including innovation, value creation and capture, interactions between stakeholder groups, activity systems, and access to resources, processes, and complementary assets. Thus we argued that business ecosystems potentially impact all four components of a business model - the problem space by establishing the context in which opportunities are discovered and shaped, SVPs by enabling access to complementors and collaborators that can strengthen the value propositions to other stakeholder groups, the profit formula by reducing cost structures, increasing operational efficiencies, and improving access to sources of revenue, and capabilities by enabling access to resources and processes that would otherwise be unavailable.

Our empirical results provide some early-stage evidence on the connections between business ecosystem participation and new venture business models. We found that ventures participating more intensely in the Lead To Win 'job-creation engine' crafted business models that were more differentiated, more sophisticated, and changed in more aspects over time, and reported a greater breadth of benefits from the ecosystem. We offer our exploratory results as a contribution to the theory and practice of technology entrepreneurship.

In addition to the results reported here, we also considered other variables and associations. For example, we explored whether breadth of participation operationalised as either the number of field setting categories or number of elements in which the founder participated (i.e., Table 9) - could explain any of the business model variables. However we could discern no strong patterns to support propositions. It could be that there are no relationships between other variables. More likely, however, we speculate that effect sizes may be too small to detect with only six cases and the noisy data of an exploratory study but may be revealed with sharper instruments and larger data sets.

Our second contribution is representations of our business ecosystem field setting using five frameworks from the literature. Our decision to employ multiple frameworks was fortuitous - we found that no single framework could fully specify the field setting. Both of our ecosystem representations combined findings from two or more frameworks; both representations are coherent but neither is complete. Until researchers develop better operational representations of business ecosystem field settings, we recommend that researchers employ multiple frameworks.

Like all early-stage exploratory research, our results should be interpreted with caution. Further work is needed to establish external validity by replicating these results in other ecosystems. Theory-testing is a second area for future research; this could proceed by reformulating our propositions as testable hypotheses for large-sample statistical tests. A third area is the reciprocal relationship of how firm business models impact business ecosystems; for example, sustainability of a business ecosystem may depend on viable business models for keystone organisations and niche players (Iansiti and Levien, 2004). 


\section{Conclusions}

This article explored the impact of new venture participation in a business ecosystem on new venture business models. More intense participation in the Lead To Win ecosystem was associated with higher business model differentiation, higher business model sophistication, greater extent of business model change, and greater breadth of benefits. Furthermore, we report two coherent representations of Lead To Win obtained by systematically applying frameworks from the literature.

These results are encouraging for technology entrepreneurs seeking to launch and grow new ventures. Constrained by limited resources, dependent on the innovations and actions of others, and facing global competition (Bailetti, 2012; Muegge, 2013; Bailetti and Hurley, 2013), entrepreneurs in business ecosystems can achieve more, learn faster, and reach farther than otherwise possible. Prior research has associated improved venture performance with business models that are more novel (Zott and Amit, 2007, 2008), more differentiated (Shin and Park, 2009; Cennamo and Santalo, 2013), more open (Chesbrough, 2006; Chanal and Caron-Fason, 2010; Frankenberger et al., 2013), and change over time rather than remaining static (Chesbrough and Rosenbloom, 2002; Amit and Zott, 2012). Entrepreneurs should therefore seek out business ecosystems matched to their needs and then participate intensely in those ecosystems.

Our results have implications also for other groups that benefit from high-performing new ventures. Our results imply that early-stage investors should deliberately seek out ventures participating more intensely in business ecosystems and perhaps become ecosystem participants themselves. Policy makers should create conditions where business ecosystems can thrive. Economic development agencies should increase their own participation in regional ecosystems, contribute resources and encourage participation by ventures they support.

\section{References}

Adner, R. (2006) 'Match your innovation strategy to your innovation ecosystem', Harvard Business Review, Vol. 84, No. 1, pp.98-107.

Adner, R. (2012) The Wide Lens: A New Strategy for Innovation, Portfolio/Penguin, New York.

Adner, R. and Kapoor, R. (2010) 'Value creation in innovation ecosystems: how the structure of technological interdependence affects firm performance in new technology generations', Strategic Management Journal, Vol. 31, No. 3, pp.306-333.

Al-Debei, M.M. and Avison, D. (2010) 'Developing a unified framework of the business model concept', European Journal of Information Systems, Vol. 19, No. 3, pp.359-376.

Aldrich, H. (2011) An Evolutionary Approach to Entrepreneurship: Selected Essays, Edward Elgar, Cheltenham.

Amit, R. and Zott, C. (2001) 'Value creation in e-business', Strategic Management Journal, Vol. 22, Nos. 6/7, pp.493-520.

Amit, R. and Zott, C. (2012) 'Creating value through business model innovation', MIT Sloan Management Review, Vol. 53, No. 3, pp.41-49.

Anderson, C. (2010) Free: How Today's Smartest Businesses Profit By Giving Something For Nothing, Hyperion, New York.

Anderson, J.C., Narus, J.A. and van Rossum, W. (2006) 'Customer value propositions in business markets', Harvard Business Review, Vol. 84, No. 3, pp.90-99. 
Baden-Fuller, C. and Mangematin, V. (2013) 'Business models: a challenging agenda', Strategic Organization, Vol. 11, No. 4, pp.418-427.

Baden-Fuller, C. and Morgan, M.S. (2010) 'Business models as models', Long Range Planning, Vol. 43, Nos. 2-3, pp.156-171.

Bailetti, T. (2009a) 'Growing creative companies in strong ecosystems', Ottawa Business Journal, 30 October [online] http://www.obj.ca/Other/Archives/2009-10-30/article-2302330/Growingcreative-companies-in-strong-ecosystems/1 (accessed 1 September 2013).

Bailetti, T. (2009b) 'Biz ecosystem need creates opportunities for local firms', Ottawa Business Journal, 2 December [online] http://www.obj.ca/Other/Archives/2009-12-02/article-2253863/ Biz-ecosystem-need-creates-opportunities-for-local-firms/1 (accessed 1 September 2013).

Bailetti, T. (2010a) 'Technical entrepreneurs benefits from business ecosystem', Open Source Business Resource, February [online] http://osbr.ca/article/325 (accessed 1 September 2013).

Bailetti, T. (2010b) 'Blueprint and approach to grow revenue in small technology companies', Open Source Business Resource, June [online] http://osbr.ca/article/355 (accessed 1 September 2013).

Bailetti, T. (2010c) 'Keystone off-the-shelf', Open Source Business Resource, September [online] http://osbr.ca/article/377 (accessed 1 September 2013).

Bailetti, T. (2012) 'Technology entrepreneurship: overview, definition, and distinctive aspects', Technology Innovation Management Review, Vol. 2, No. 2, pp.5-12 [online] http://timreview.ca/article/520 (accessed 1 September 2016).

Bailetti, T. and Bot, S. (2013) 'An ecosystem-based job-creation engine fuelled by technology entrepreneurs', Technology Innovation Management Review, Vol. 3, No. 2, pp.31-40 [online] http://timreview.ca/article/658 (accessed 1 September 2016).

Bailetti, T. and Hudson, D. (2009) 'Value co-creation: lessons from Lead To Win ecosystem', Open Source Business Resource, December [online] http://osbr.ca/article/308 (accessed 1 September 2013).

Bailetti, T. and Hurley, B. (2013) Best of TIM Review for Technology Entrepreneurs, Talent First Network, Ottawa.

Bailetti, T. and Prattico, L. (2011) 'Carleton Entrepreneurs: The first keystone off-the-shelf application', Technology Innovation Management Review, April [online] http://timreview.ca/ article/433.

Bailetti, T., Bot, S.D., Duxbury, T., Hudson, D., McPhee, C., Muegge, S., Weiss, M., Wells, J. and Westerlund, M. (2012) 'An overview of four issues on technology entrepreneurship in the TIM Review', Technology Innovation Management Review, Vol. 2, No. 5, pp.28-34 [online] http://timreview.ca/article/557 (accessed 1 September 2016).

Bailetti, T., Weiss, M., Muegge, S. and Westerlund, M. (2014) 'Lead To Win: an ecosystem approach to making universities more entrepreneurial', Accepted for inclusion in the UIIN Good Practice Series 2014, University Industry Innovation Network.

Baldwin, C. and von Hippel, E. (2011) 'Modeling a paradigm shift: from producer innovation to user and open collaborative innovation', Organization Science, Vol. 22, No. 6, pp.1399-1417.

Baldwin, C.Y. and Clark, K.B. (2000) Design Rules: Volume 1: The Power of Modularity, MIT Press, Cambridge.

Baldwin, C.Y. and Clark, K.B. (2006) 'The architecture of participation: does code architecture mitigate free riding in the open source development mode?', Management Science, Vol. 52, No. 7, pp.1116-1127.

Baldwin, C.Y. and Woodard, C.J. (2009) 'The architecture of platforms: a unified view', in Gawer, A. (Ed.): Platforms, Markets, and Innovation, pp.19-44, Edward Elgar, Northampton.

Bingham, C.B. and Eisenhardt, K.M. (2011) 'Rational heuristics: the 'simple rules' that strategists learn from process experience', Strategic Management Journal, Vol. 32, No. 13, pp.1437-1464. 
Blank, S.G. (2013) 'Why the lean start-up changes everything', Harvard Business Review, Vol. 91, No. 5, pp.64-72.

Boudreau, K.J. and Hagiu, A. (2009) 'Platform rules: multisided platforms as regulators', in Gawer, A. (Ed.): Platforms, Markets, and Innovation, pp.163-191, Edward Elgar, Northampton.

Brandenburger, A.M. and Nalebuff, B.J. (1996) Co-opeticion, HarperCollins Business, New York.

Brown, S.L. and Eisenhardt, K.M. (1997) 'The art of continuous change: linking complexity theory and time-paced evolution in relentlessly shifting organizations', Administrative Science Quarterly, Vol. 42, No. 1, pp.1-34.

Buchanan, J.M. (1965) ‘An economic theory of clubs', Economica, Vol. 32, No. 125, pp.1-14.

Cennamo, C. and Santalo, J. (2013) 'Platform competition: Strategic trade-offs in platform markets', Strategic Management Journal, Vol. 34, No. 11, pp.1331-1350.

Chanal, V. and Caron-Fason, M. (2010) 'The difficulties involved in developing business models open to innovation communities: the case of a crowdsourcing platform',M@n@gement, Vol. 13, No. 4, pp.318-341.

Chesbrough, H.W. (2003) Open Innovation: The New Imperative for Creating and Profiting from Technology, Harvard Business School Press, Boston.

Chesbrough, H.W. (2006) Open Business Models: How to Thrive in the New Innovation Landscape, Harvard Business School Press, Boston.

Chesbrough, H.W. and Rosenbloom, R.S. (2002) 'The role of the business model in capturing value from innovation: evidence from Xerox Corporation's technology spin-off companies', Industrial and Corporate Change, Vol. 11, No. 3, pp.529-555.

Chesbrough, H.W., Vanhaverbeke, W. and West, J. (2006) Open Innovation: Researching a New Paradigm, Oxford University Press, Oxford.

Christensen, C.M. (2006) 'The ongoing process of building a theory of disruption', Journal of Product Innovation Management, Vol. 23, No. 1, pp.39-55.

Christensen, C.M., Anthony, S.D., Berstell, G. and Nitterhouse, D. (2007) 'Finding the right job for your product', MIT Sloan Management Review, Vol. 48, No. 3, pp.38-47.

Christensen, C.M., King, S., Verlinden, M. and Yang, W. (2008) 'The new economics of semiconductor manufacturing', IEEE Spectrum, Vol. 45, No. 5, pp.25-29.

Coombes, P.H. and Nicholson, J.D. (2013) 'Business models and their relationship with marketing: a systematic literature review', Industrial Marketing Management, Vol. 42, No. 5, pp.656-664.

Couch, A. (2012) 'Change the system: many 'ants' make much work and provide a solution for economic woe', Carleton University Magazine, summer [online] http://cualumni.carleton.ca/ magazine/summer-2012/change-the-system-many-ants-make-much-work-and-provide-asolution-for-economic-woe (accessed 1 September 2016).

Cusumano, M.A. (2004) The Business of Software, Free Press, New York.

Cusumano, M.A. (2010) Staying Power: Six Enduring Principles for Managing Strategy \& Innovation in an Uncertain World, Oxford University Press, Oxford.

Davis, J.P. and Eisenhardt, K.M. (2011) 'Rotating leadership and collaborative innovation: Recombining processes in symbiotic relationships', Administrative Science Quarterly, Vol. 56, No. 2, pp.159-201.

Edelman, B. (2015) 'How to launch your digital platform', Harvard Business Review, Vol. 93, No. 4, pp.90-97.

Eisenhardt, K.M. (1989) 'Building theories from case study research', Academy of Management Review, Vol. 14, No. 4, pp.532-550.

Eisenhardt, K.M. and Graebner, M.E. (2007) 'Theory building from cases: opportunities and challenges', Academy of Management Journal, Vol. 50, No. 1, pp.25-32. 
Eisenhardt, K.M., Graebner, M.E. and Sonenshein, S. (2016) 'Grand challenges and inductive methods: Rigor without rigor mortis’, Academy of Management Journal, Vol. 59, No. 4, pp.1113-1123.

Evans, D.S. (2009) 'How catalysts ignite: the economics of platform-based start-ups', in Gawer, A. (Ed.): Platforms, Markets, and Innovation, pp.99-128, Edward Elgar, Northampton.

Evans, D.S. and Schmalensee, R. (2016) Matchmakers: The New Economics of Multisided Platforms, Harvard Business Review Press, Boston.

Foddy, W. (1993) Constructing Questions for Interviews and Questionnaires: Theory and Practice in Social Research, Cambridge University Press, Cambridge.

Frankenberger, K., Weiblen, T. and Gassmann, O. (2013) 'Network configuration, customer centricity, and performance of open business models: a solution provider perspective', Industrial Marketing Management, Vol. 42, No. 5, pp.671-682.

Friedman, T. (2005) The World is Flat: A Brief History of the Twenty-First Century, Farrar, Straus and Giroux, New York.

Gawer, A. (2014) 'Bridging differing perspectives on technological platforms: toward an integrative framework', Research Policy, Vol. 43, No. 7, pp.1239-1249.

Gawer, A. (Ed.) (2009) Platforms, Markets and Innovation, Edward Elgar, Northampton.

Gawer, A. and Cusumano, M.A. (2002) Platform Leadership: How Intel, Microsoft, and Cisco Drive Industry Innovation, Harvard Business School Press, Boston.

Gawer, A. and Cusumano, M.A. (2014) 'Industry platforms and ecosystem innovation', Journal of Product Innovation Management, Vol. 31, No. 3, pp.417-433.

George, G. and Bock, A.J. (2011) 'The business model in practice and its implications for entrepreneurship research', Entrepreneurship Theory and Practice, Vol. 35, No. 1, pp.83-111.

George, G. and Bock, A.J. (2012) Models of Opportunity: How Entrepreneurs Design Firms to Achieve the Unexpected, Cambridge University Press, Cambridge.

Hagiu, A. (2007) 'Merchant or two-sided platform?', Review of Network Economics, Vol. 6, No. 2, pp.115-153.

Hallen, B.L. and Eisenhardt, K.M. (2012) 'Catalyzing strategies and efficient tie formation: how entrepreneurial firms obtain investment ties', Academy Of Management Journal, Vol. 55, No. 1, pp.35-70.

Hess, C. and Ostrom, E. (2007) Understanding Knowledge as a Commons: From Theory to Practice, MIT Press, Cambridge.

Hickman, S. (2013) 'Bailetti wins award for connecting foreign talent with local startups', Carleton Now, March [online] http://carletonnow.carleton.ca/march-2013/bailetti-wins-award-forconnecting-foreign-talent-with-local-startups/ (accessed 1 September 2016).

Iansiti, M. and Levien, R. (2004) 'Strategy as ecology', Harvard Business Review, Vol. 82, No. 3, pp.68-78.

Iansiti, M. and Richards, G.L. (2006) 'The information technology ecosystem: structure, health, and performance', Antitrust Bulletin, Vol. 51, No. 1, pp.77-110.

Isckia, T. (2009) 'Amazon's evolving ecosystem: a cyber-bookstore and application service provider', Canadian Journal of Administrative Sciences, Vol. 26, No. 4, pp.332-343.

Iyer, B. and Davenport, T.H. (2008) 'Reverse engineering Google's innovation machine', Harvard Business Review, Vol. 86, No. 4, pp.58-68.

Jick, T.D. (1979) 'Mixing qualitative and quantitative methods: triangulation in action', Administrative Science Quarterly, Vol. 24, No. 4, pp.602-611.

Johnson, M., Christensen, C.M. and Kagermann, H. (2008) 'Reinventing your business model', Harvard Business Review, Vol. 86, No. 12, pp.57-68.

Johnson, M.W. (2010) Seizing the Whitespace: Business Model Innovation for Growth and Renewal, Harvard Business Press, Boston. 
Kapoor, R. (2013) 'Collaborating with complementors: what do firms do?', Advances in Strategic Management, Vol. 30, pp.3-25.

Kapoor, R. and Adner, R. (2007) 'Technology interdependence and the evolution of semiconductor lithography', Solid State Technology, Vol. 50, No. 11, pp.51-54.

Katz, M.L. and Shapiro, C. (1985) 'Network externalities, competition, and compatibility', American Economic Review, Vol. 75, No. 3, pp.424-440.

MacCormack, A., Rusnak, J. and Baldwin, C. (2006) 'Exploring the structure of complex software designs: an empirical study of open source and proprietary code', Management Science, Vol. 52, No. 7, pp.1015-1030.

MacCormack, A., Verganti, R. and Iansiti, M. (2001) 'Developing products on 'internet time': the anatomy of a flexible development process', Management Science, Vol. 47, No. 1, pp. $133-150$.

Magretta, J. (2002) 'Why business models matter', Harvard Business Review, Vol. 80, No. 5, pp.86-92.

Makienko, J. and Misaka, A. (2011) 'A progress report on the keystone off-the-shelf project', Open Source Business Resource, April [online] http://timreview.ca/article/432 (accessed 1 September 2016).

Merton, R.C. (1973) 'Theory of rational option pricing', Bell Journal of Economics and Management Science, Vol. 4, No. 1, pp.141-183.

Messerschmitt, D.G. and Szyperski, C. (2003) Software Ecosystem: Understanding an Indispensable Technology and Industry, MIT Press, Cambridge, MA.

Miles, M. and Huberman, M. (1994) Qualitative Data Analysis: An Expanded Sourcebook, Sage Publications, Newbury Park.

Mintzberg, H., Lampel, J. and Ahlstrand, B. (1998) Strategy Safari: A Guided Tour through the Wilds of Strategic Management, Free Press, New York.

Moore, G.A. (1999) Crossing the Chasm, revised ed., HarperBusiness, New York.

Moore, J.F. (1993) 'Predators and prey: a new ecology of competition', Harvard Business Review, Vol. 71, No. 3, pp.75-86.

Moore, J.F. (1996) The Death of Competition, HarperBusiness, New York.

Moore, J.F. (2006) 'Business ecosystems and the view from the firm', Antitrust Bulletin, Vol. 51, No. 1, pp.31-76.

Morris, M., Schindehutte, M. and Allen, J. (2005) 'The entrepreneur's business model: toward a unified perspective', Journal of Business Research, Vol. 58, No. 6, pp.726-735.

Muegge, S. (2011a) 'Business ecosystems as metaphor, label, and analogy', Paper presented at the Academy of Management 2011 Annual Meeting, 12-16 August, San Antonio, Texas.

Muegge, S. (2011b) 'Business ecosystems as institutions of participation: a systems perspective on community-developed platforms', Technology Innovation Management Review, Vol. 1, No. 2 , pp.4-13 [online] http://timreview.ca/article/495 (accessed 1 September 2016).

Muegge, S. (2012) 'Business model discovery by technology entrepreneurs', Technology Innovation Management Review, Vol. 2, No. 4, pp.5-16 [online] http://timreview.ca/article/545 (accessed 1 September 2016).

Muegge, S. (2013) 'Platforms, communities, and business ecosystems: lessons learned about technology entrepreneurship in an interconnected world', Technology Innovation Management Review, Vol. 3, No. 2, pp.5-15 [online] http://timreview.ca/article/655 (accessed 1 September 2016).

Muegge, S. and Haw, C. (Eds.) (2013) Business Models for Entrepreneurs and Startups: Best of TIM Review, Talent First Network, Ottawa.

Muegge, S.M. and Grant, G.G. (2013) 'An institutional perspective on participation in business ecosystems, communities, and platforms', Paper presented at the Academy of Management 2013 Annual Meeting, 9-13 August, Lake Buena Vista, Florida. 
Nederhof, A.J. (1985) 'Methods of coping with social desirability bias: a review', European Journal of Social Psychology, Vol. 15, No. 3, pp.263-280.

North, D.C. (1990) Institutions, Institutional Change and Economic Performance, Cambridge University Press, Cambridge.

Osterwalder, A. and Pigneur, Y. (2010) Business Model Generation: A Handbook for Visionaries, Game Changers, and Challengers, John Wiley \& Sons, Hoboken, New Jersey.

Ostrom, E. (1990) Governing the Commons: The Evolution of Institutions for Collective Action, Cambridge University Press, Cambridge.

Ostrom, E. (2005) Understanding Institutional Diversity, Princeton University Press, Princeton.

Ottawa Business Journal (2009a) 'Program looks to conquer ghosts of meltdowns past', 8 May [online] http://www.obj.ca/Other/Archives/2009-05-08/article-2151716/Program-looks-toconquer-ghosts-of-meltdowns-past/1 (accessed 1 September 2013).

Ottawa Business Journal (2009b) 'Lead To Win reflects a local need', 26 June [online] http://www.obj.ca/Other/Archives/2009-06-26/article-2151443/Lead-To-Win-reflects-a-localneed/1 (accessed 1 September 2013).

Ottawa Business Journal (2009c) 'Close to \$1 million raised for Lead To Win start-ups: founder', 11 September [online] http://www.obj.ca/Other/Archives/2009-09-11/article-2274585/Closeto-\%241-million-raised-for-Lead-to-Win-startups\%3A-founder/1 (accessed 1 September 2013).

Ottawa Business Journal (2011) 'Carleton establishes entrepreneurial institute', 12 August [online] http://www.obj.ca/Local/2011-08-12/article-2704869/Carleton-establishes-entrepreneurialinstitute/1 (accessed 1 September 2013).

Palo, T. and Tähtinen, J. (2013) 'Networked business model development for emerging technology-based services', Industrial Marketing Management, Vol. 42, No. 5, pp.773-782.

Parker, G.G., van Alstyne, M.W. and Choudary, S.P. (2016) Platform Revolution: How Networked Markets are Transforming the Economy - and How to Make them Work for You, Norton, New York.

Parnas, D.L. (1972) 'On the criteria to be used in decomposing systems into modules', Communications of the ACM, Vol. 15, No. 12, pp.1053-1158.

Pfeffer, J. and Salancik, G.R. (1978) The External Control of Organizations: A Resource Dependence Perspective, Harper \& Row, New York.

Plé, L., Lecocq, X. and Angot, J. (2010) 'Customer-integrated business models: a theoretical framework',M@n@gement, Vol.13,No.4,pp.226-265.

Ritala, P., Golnam, A. and Wegmann, A. (2014) 'Coopetition-based business models: the case of Amazon.com', Industrial Marketing Management, Vol. 43, No. 2, pp.236-249.

Rochet, J.C. and Tirole, J. (2003) 'Platform competition in two-sided markets', Journal of the European Economic Association, Vol. 1, No. 4, pp.990-1029.

Rochet, J.C. and Tirole, J. (2006) 'Two-sided markets: a progress report', RAND Journal of Economics, Vol. 37, No. 3, pp.645-667.

Rogers, E.M. (2003) Diffusion of Innovations, 5th ed., Free Press, New York.

Rubinstein, D. (2015) 'Lead To Win is a winner: Carleton ecosystem among top 10 in North America', Carleton University: Our Stories, 4 November [online] https://carleton.ca/ourstories/story/lead-to-win-is-a-winner/ (accessed 1 September 2013).

Sandler, T. and Tschirhart, J. (1997) 'Club theory: thirty years later', Public Choice, Vol. 93, Nos. 3-4, pp.335-355.

Scott, W.R. and Davis, G.F. (2007) Organizations and Organizing: Rational, Natural, and Open System Perspectives, Pearson Prentice Hall, Upper Saddle River, NJ.

Shapiro, C. and Varian, H.R. (1999) Information Rules: A Strategic Guide to the Network Economy, Harvard Business School Press, Boston. 
Shin, J. and Park, Y. (2009) 'On the creation and evaluation of e-business model variants: the case of auction', Industrial Marketing Management, Vol. 38, No. 3, pp.324-337.

Shirky, C. (2008) Here comes Everybody: The Power of Organizing without Organizing, Penguin Press, New York.

Simmons, G., Palmer, M. and Truong, Y. (2013) 'Inscribing value on business model innovations: insights from industrial projects commercializing disruptive digital innovations', Industrial Marketing Management, Vol. 42, No. 5, pp.744-754.

Simon, H.A. (1996) The Sciences of the Artificial, 3rd ed., MIT Press, Cambridge.

Singer, J. and Dexter, D. (2011) 'Building an infrastructure to support women founders: Lead To Win for Women', Open Source Business Resource, July [online] http://osbr.ca/article/455 (accessed 1 September 2013).

Symons, C. (2012) 'Nine local Lead To Win startups poised to receive grants', Ottawa Business Journal, March issue [online] http://www.obj.ca/Technology/2012-03-16/article2929448/Nine-local-Lead-to-Win-startups-poised-to-receive-grants/1 (accessed 1 September 2013).

Teece, D.J. (2009) Dynamic Capabilities and Strategic Management, Oxford University Press, Oxford.

Teece, D.J. (2010) 'Business models, business strategy and innovation', Long Range Planning, Vol. 43, Nos. 2-3, pp.172-194.

Timmers, P. (1998) 'Business models for electronic markets', Electronic Markets, Vol. 8, No. 2, pp.3-8.

UBI Global (2015) 'North American top 10 university business incubators 2015', Top Business Incubation Rankings 2015 [online] http://ubi-global.com/research/ranking/rankings2015/\#na2015 (accessed 1 September 2016).

Wacheski, T. (2011) 'Anystone technologies: lessons from the first year of a mobile applications startup', Open Source Business Resource, August [online] http://osbr.ca/article/464 (accessed 1 September 2013).

West, J. and O'Mahony, S. (2008) 'The role of participation architecture in growing sponsored open source communities', Industry and Innovation, Vol. 15, No. 2, pp.145-168.

West, J. and Wood, D. (2013) 'Evolving an open ecosystem: the rise and fall of the Symbian platform', Advances in Strategic Management, Vol. 30, pp.27-67.

Willinsky, J. (2009) The Access Principle: The Case for Open Access to Research and Scholarship, MIT Press, Cambridge.

Yin, R.K. (2003) Case Study Research: Design and Methods, Sage Publications, Newbury Park.

Yin, R.K. (2011) Qualitative Research from Start to Finish, Guilford Press, New York.

Yoffie, D. and Kwak, M. (2006) 'With friends like these: the art of managing complementors', Harvard Business Review, Vol. 84, No. 9, pp.89-98.

Yoo, Y. (2013) 'The tables have turned: how can the information systems field contribute to technology and innovation management research?', Journal Of The Association For Information Systems, Vol. 14, No. 5, pp.227-236.

Zott, C. and Amit, R. (2007) 'Business model design and the performance of entrepreneurial firms', Organization Science, Vol. 18, No. 2, pp.181-199.

Zott, C. and Amit, R. (2008) 'The fit between product market strategy and business model: implications for firm performance', Strategic Management Journal, Vol. 29, No. 1, pp.1-26.

Zott, C. and Amit, R. (2013) 'The business model: a theoretically anchored robust construct for strategic analysis', Strategic Organization, Vol. 11, No. 4, pp.403-411.

Zott, C., Amit, R. and Massa, L. (2011) 'The business model: recent developments and future research', Journal of Management, Vol. 37, No. 4, pp.1019-1042. 